\title{
Review \\ Endoglin in the Spotlight to Treat Cancer
}

\author{
Teresa González Muñoz ${ }^{1,+}+\mathbb{D}$, Ana Teresa Amaral ${ }^{2, *, \dagger}$, Pilar Puerto-Camacho ${ }^{2, \dagger}$, Héctor Peinado ${ }^{1, *, \ddagger(D)}$ and \\ Enrique de Álava $2,3, *, \ddagger$
}

Citation: González Muñoz, T.;

Amaral, A.T.; Puerto-Camacho, P.;

Peinado, H.; de Álava, E. Endoglin in the Spotlight to Treat Cancer. Int. J. Mol. Sci. 2021, 22, 3186. https:// doi.org/10.3390/ijms22063186

Academic Editors: Lukas J. A.

C. Hawinkels and

Marie-José Goumans

Received: 22 January 2021

Accepted: 17 March 2021

Published: 20 March 2021

Publisher's Note: MDPI stays neutral with regard to jurisdictional claims in published maps and institutional affiliations.

Copyright: (c) 2021 by the authors. Licensee MDPI, Basel, Switzerland. This article is an open access article distributed under the terms and conditions of the Creative Commons Attribution (CC BY) license (https:/ / creativecommons.org/licenses/by/ $4.0 /)$.
1 Microenvironment and Metastasis Group, Department of Molecular Oncology, Spanish National Cancer Research Center (CNIO), 28029 Madrid, Spain; mtgonzalezm@cnio.es

2 Molecular Pathology of Sarcomas, Institute of Biomedicine of Sevilla (IBiS), Virgen del Rocio University Hospital, CSIC, University of Sevilla, CIBERONC, 41013 Seville, Spain; mpilarpuertocamacho@gmail.com

3 Department of Normal and Pathological Cytology and Histology, School of Medicine, University of Seville, 41009 Seville, Spain

* Correspondence: amonteiro-ibis@us.es (A.T.A.); hpeinado@cnio.es (H.P.); edealava-ibis@us.es (E.d.Á.)

$\dagger$ These authors contributed equally to this work.

$\ddagger$ These authors shared senior authorship.

\begin{abstract}
A spotlight has been shone on endoglin in recent years due to that fact of its potential to serve as both a reliable disease biomarker and a therapeutic target. Indeed, endoglin has now been assigned many roles in both physiological and pathological processes. From a molecular point of view, endoglin mainly acts as a co-receptor in the canonical TGF $\beta$ pathway, but also it may be shed and released from the membrane, giving rise to the soluble form, which also plays important roles in cell signaling. In cancer, in particular, endoglin may contribute to either an oncogenic or a non-oncogenic phenotype depending on the cell context. The fact that endoglin is expressed by neoplastic and non-neoplastic cells within the tumor microenvironment suggests new possibilities for targeted therapies. Here, we aimed to review and discuss the many roles played by endoglin in different tumor types, as well as the strong evidence provided by pre-clinical and clinical studies that supports the therapeutic targeting of endoglin as a novel clinical strategy.
\end{abstract}

Keywords: endoglin; tumor; microenvironment; targeted therapy; biomarker

\section{Introduction}

Endoglin (ENG), also known as CD105, is a transmembrane receptor that was initially associated with neo-angiogenesis, yet it is currently known to be involved in several physiological and malignant processes (Figure 1). In this review, we describe how the molecular features of this protein make it an attractive therapeutic target, a reliable disease biomarker, and an important (yet somewhat controversial) player that modulates malignant phenotypes in cancer. 


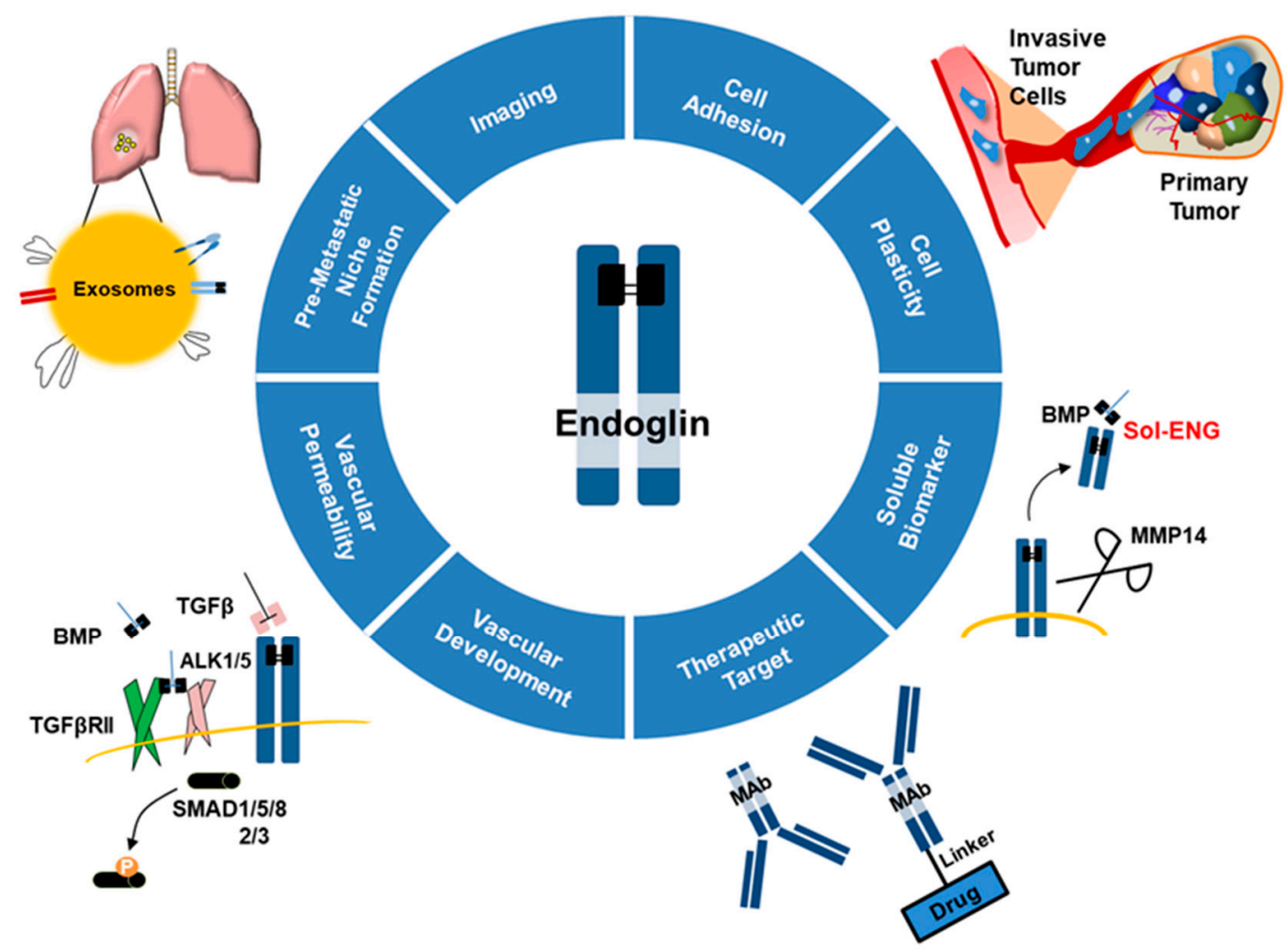

Figure 1. Endoglin in physiology and pathology. Scheme depicting how endoglin is associated with many physiological and malignant processes and might be a reliable biomarker and a therapeutic target depending on the cellular context. Transforming growth factor $\beta$ (TGF $\beta$ ), transforming growth factor $\beta$ receptor II (TGF $\beta$ RII), bone morphogenic protein (BMP), activin-like kinase (ALK), monoclonal antibody (MAb), matrix metalloproteinase 14 (MMP14), soluble endoglin (Sol-ENG).

\section{Endoglin: Molecular Features}

The human gene encoding ENG is located on the long arm of chromosome 9 (9q34.11) [1]. The promoter of this gene lacks consensus TATA and CAAT boxes, yet it contains GC-rich regions and consensus motifs for specific modulators [2]. Indeed, the specificity protein-1 (Sp1) site at -37 seems to be necessary for the basal and transforming growth factor $\beta$ (TGF $\beta$ )-induced transcription of ENG [3]. The gene product is a protein of 658 amino acids (aa), and it is arranged as a disulfide-linked homodimer $[4,5]$ that establishes itself as an integral membrane glycoprotein [5]. As its glycosylation status may differ across tissues, the final molecular weight of ENG can vary between 90 and $95 \mathrm{kDa}$ for each subunit [6]. The protein has three well-differentiated structures: (1) a 586 aa extracellular region (ectodomain), (2) a 25 aa hydrophobic transmembrane domain, (3) and a cytoplasmic tail of variable length $[5,6]$.

The extracellular region contains an N-terminal signal peptide of 25 aa that is followed by a sequence of unknown function, an orphan domain (aa 26-330) that is enriched in $\mathrm{N}$-glycosylation-prone residues, and a zona pellucida (ZP)-like domain (aa 349-576) [6-8]. The ZP domain is a 260 aa cysteine (Cys)-rich sequence that is found in a family of proteins with similar structural features [7]. In particular, the Cys350 aa present in this part of the ectodomain is the Cys residue that participates in the disulfide-bond dimerization of the homomeric ENG [5-9]. Interestingly, the ZP domain of human ENG contains an arginine-glycine-aspartic acid (RGD) tripeptide that is typically found in extracellular matrix (ECM)-associated proteins, a sequence recognized by integrins that is relevant in cell adhesion [6-10]. However, the RGD motif has not been detected in the ENG sequence derived from rat [11], mouse [8], porcine [12] or chicken [13], nor in other protein counterparts. Notwithstanding, they do preserve the acidic residue (aspartic acid or glutamic acid) that is necessary for the interaction with the integrin $\beta$ subunits $[14,15]$. 
The sequences of the transmembrane and cytoplasmic domains of ENG are highly conserved across species [8-11]. Moreover, these regions share a strong similarity with the transmembrane and cytoplasmic domains of betaglycan (71\%) [16]. Within the cytoplasmic domain, a serine-methionine-alanine (SMA) tripeptide constitutes the C-terminal stretch of the protein, a sequence that can be considered a PSD-95/Discs-large/ZO1 (PDZ)-binding motif [17]. In fact, this motif has been demonstrated to mediate the interaction of ENG with the PDZ domain-containing protein, $\mathrm{G}$ alpha interacting protein (GAIP)-interacting protein C-terminus (GIPC), which regulates the retention of ENG at the endothelial cell (EC) surface $[18,19]$.

The ENG messenger RNA (mRNA) is alternatively spliced, producing two isoforms that differ in the length of their cytoplasmic tail: 14 aa (S-ENG) or 41 aa (L-ENG) long [5]. Both isoforms have the first seven juxtamembrane residues of their cytoplasmic domains, although S-ENG lacks the PDZ-binding motif $[5,7,18]$. The intron located between exons 13 and 14, which contains a TAG stop codon, is spliced out of L-ENG mRNA, whereas it is retained by splicing factor-2 in S-ENG mRNA, allowing the generation of a shorter transcript $[5,20]$. The L-ENG is the isoform predominantly expressed in most tissues [5], although S-ENG might play key roles in some pathological contexts $[21,22]$ as described later in this review.

\section{The Physiological Role of Endoglin}

Based on the aa sequence similarity between ENG and the TGF $\beta$ co-receptor betaglycan [16], the role of ENG in TGF $\beta$ signaling has been studied intensely, which has been crucial to elucidating its mode of action [1]. In fact, there is considerable evidence regarding ENG and its regulation of the TGF $\beta$ pathway.

The TGF $\beta$ signaling plays a crucial role in the proliferation, migration, differentiation, and apoptosis [23]. The human TGF $\beta$ superfamily comprises TGF $\beta s(1,2$, and 3$)$, bone morphogenic proteins (BMPs), activins (A and $\mathrm{B})$, and growth differentiation factors (GDFs) [23]. Seven TGF $\beta$ type-I receptors (TGF $\beta$ RI: activin-like kinases (ALKs) 1-7) and five TGF $\beta$ type-II receptors (TGF $\beta$ RII) have been reported to be expressed in the human genome [23]. In the canonical signaling pathway, after binding of the ligand to TGF $\beta$ RII, it activates and transphosphorylates TGF $\beta$ RI, which subsequently transduces the signal by phosphorylating the downstream receptor-regulated SMAD (R-SMAD) molecules [23]. The involvement of different TGF $\beta$ RI (ALKs) can provoke the induction of different RSMADs [24]. Indeed, the activation of ALK5 triggers phosphorylation of SMAD2 and SMAD3, whereas activated ALK1 mediates SMAD1, SMAD5, and SMAD8 phosphorylation [24]. Phosphorylated SMAD $2 / 3$ or $1 / 5 / 8$ specifically associate with a common partner SMAD (co-SMAD) (SMAD4 in mammals) and these complexes are translocated to the nucleus, where they modulate the transcription of specific target genes [24-28]. In the case of non-canonical TGF $\beta$ signaling, several kinases can be activated, such as mitogen activated protein kinases (MAPKs), extracellular signal-regulated kinase (ERK), c-Jun N-terminal kinase (JNK), phosphatidylinositol-3-kinase (PI3K), or Rho-associated coiled-coil kinase (ROCK) [29,30].

ENG has been widely described to act as a co-receptor of the TGF $\beta$ cytokine superfamily [16]. It is known that ENG forms a heterodimeric receptor complex with TGF $\beta$ RI and TGF $\beta$ RII, modulating the ligand-receptor interaction [18]. Specifically, in association with TGF $\beta$ RII ENG binds TGF $\beta 1$, TGF $\beta 3$, activin A and BMP-7, it binds to BMP-2 in the presence of TGF $\beta$ RI, and it can also bind directly to BMP-9 or -10 [16,31-33]. Upon ligand binding, activated TGF $\beta$ RII interacts with the extracellular and cytoplasmic domains of ENG [34]. At this point, the kinase activity of TGF $\beta$ RII phosphorylates the cytoplasmic serine (Ser) 631 and 635 residues of ENG $[18,34]$. This association enhances the phosphorylation status of TGF $\beta$ RI, which subsequently transduces the signal by phosphorylating R-SMADs [18,34]. Moreover, ENG interacts with TGF $\beta$ RI through two interaction sites in the extracellular domain and one in the cytoplasmic domain [18,34]. TGF $\beta$ RI phosphorylates ENG at threonine (Thr) residues and it is then released from the complex [35]. 
Interestingly, L-ENG can be phosphorylated at three different Ser/Thr phosphorylation sites 8-fold more strongly than S-ENG [35].

ENG plays an essential role during embryonic development, with ENG deficiency causing early embryonic lethality in mice [36,37]. Many studies have demonstrated that ENG is expressed in the mesoderm and that regulates hematopoiesis at early stages of gestation through the ALK1-SMAD1/5 pathway [38-40]. More specifically, ENG is required for the specification of hemangioblasts, embryonic progenitors of the hematopoietic and endothelial lineages, and for hematopoietic commitment, which is particularly important for proper myelopoiesis and erythropoiesis [39-42]. In line with these data, the hematopoietic and endothelial progenitors that emerge in close association during embryogenesis can be distinguished by their levels of ENG [43]. This regulation of ENG expression is associated with the modulation of TGF $\beta$ /BMP signaling, which ultimately controls definitive hematopoiesis [43]. Likewise, ENG regulates the divergence of cardiac and hematopoietic fate through BMP and Wingless/Integrated (WNT) signaling [44], and it is involved in heart septation and valve formation during early human development $[45,46]$. In this context, ENG is also necessary for correct adult erythropoietic development [47].

Given the essential roles of ENG during early development, it is no surprising that the expression of this protein is one of the criteria required to define multipotent mesenchymal stem cells (MSCs) [48]. In fact, ENG is crucial to determine the differentiation potential of several MSC populations (e.g., osteogenic, chondrogenic, adipogenic or myogenic) [49-51]. Indeed, ENG is downregulated over the time course of multi-lineage differentiation of human umbilical cord blood-derived MSCs [52,53].

In adults, ENG is predominantly expressed by active vascular ECs [1], as well as syncytiotrophoblasts [54-56], immature proerythroblasts [57], macrophages [58], bone marrow (BM) stromal cells [59], vascular smooth muscle cells (VSMCs) [60], MSCs [61], fibroblasts [62], mesangial cells [63], hematopoietic stem cells (HSCs) [64], chondrocytes [65], keratinocytes [66], periodontal ligament cells [50], hepatic stellate cells [11] and mast cells [67].

In terms of the modulation of ENG expression, its promoter is activated by TGF $\beta 1$ due to the binding of the Sp1 transcription factor [2,3]. Indeed, several studies demonstrated that TGF $\beta 1$ induces the expression of ENG in mesangial [63], HSC progenitor [64], VSMCs [60], hepatic stellate [68] and BM stromal [69] cells. Hypoxia is another well-known phenomenon that enhances ENG expression in the endothelium [70,71]. This mechanism protects ECs from apoptosis and it supports angiogenesis [70,71]. Similarly, angiotensin II upregulates ENG expression in human coronary artery ECs [72]. An opposing effect has been observed in the presence of the tumor necrosis factor $\alpha$ (TNF $\alpha$ ), which downregulates the expression of ENG in the endothelium [73].

ENG has been described to be actively involved in regulating the balance between the TGF $\beta$ and BMP signaling in many of these cell types.

In ECs, ENG promotes TGF $\beta$ / ALK1-induced SMAD1/5 responses and it indirectly inhibits the TGF $\beta$ / ALK5 signaling pathway [24], stimulating EC proliferation [74,75]. In this respect, ENG is expressed abundantly in actively proliferating ECs (wound healing, inflammation) [76-80], exerting a remarkable role in angiogenesis [36,45,79,81,82]. In line with these data, mutations in the ENG gene are responsible for hereditary hemorrhagic telangiectasia (HHT) type $1[83,84]$, an autosomal dominant vascular disorder characterized by arteriovenous malformations and frequent hemorrhages [85].

Furthermore, the balance between TGF $\beta$ /ALK1/SMAD1/5/8 and TGF $\beta$ /ALK5/ SMAD2/3 activation is also regulated by ENG in chondrocytes [86]. Similarly, ENG inhibits TGF 31 -induced ALK5/SMAD3 signaling [87] and favors the activation of the BMP7/SMAD1/5 pathway in myoblasts [88].

There is considerable evidence that the cellular response to TGF $\beta 1$ is controlled by ENG. Overexpression of L-ENG, and to a lesser extent S-ENG, antagonizes TGF $\beta 1$ mediated inhibition of EC proliferation [82-89]. Likewise, ENG overexpression impairs the inhibitory effects of TGF $\beta 1$ on the proliferation of myoblasts [87,90], monocytic cells [18,91], keratinocytes [66] and fibroblasts [92]. Apart from modulating the effects of TGF $\beta 1$ on 
proliferation, ENG is necessary to mediate the inhibition of trophoblast migration and invasion stimulated by TGF $\beta 1$ [93]. Moreover, ENG downregulates TGF $\beta 1$-induced collagen synthesis in myoblasts [94].

Likewise, ENG plays an important role in modulating cell motility and invasion depending on the cell context. In fibroblasts, ENG impairs cell migration $[95,96]$ in a non-SMAD dependent manner by regulating PI3K/protein kinase B (AKT) signaling [96]. Similarly, ENG inhibits the migration of keratinocytes [97], pericytes [98] and trophoblasts $[93,99]$. By contrast, ENG triggers the spreading of myoblasts and the migration of VSMCs $[100,101]$. Moreover, ENG promotes a pro-fibrogenic phenotype in hepatic stellate cells by enhancing the expression of vimentin, $\alpha$-smooth muscle actin and connective tissue growth factor [68,102], which suggests ENG influences the migratory capability of these cells.

In ECs, ENG regulates focal adhesions and filamentous-actin (F-actin) cytoskeletal organization via binding to the LIM-domain containing zyxin and zyxin-related protein 1 (ZRP1), thereby inhibiting EC migration [103-105]. Likewise, the interaction of ENG with $\beta$-arrestin2 results in their co-internalization in endocytic vesicles, and the suppression of TGF $\beta 1$-induced ERK activation and EC migration [106]. Moreover, through its association with the $\alpha 5 \beta 1$ integrin, ENG mediates crosstalk between this integrin and the ENG/ALK1 complex, selectively augmenting SMAD1/5/8 phosphorylation [107]. This activation of the SMAD1/5/8 pathway suppresses EC migration and apoptosis, promoting capillary stability and angiogenesis [107]. In this line, the PDZ domain-containing GIPC interacts with and stabilizes ENG at the cell surface to potentiate SMAD1/5/8 signaling and inhibit EC migration [19]. This ENG/GIPC complex also mediates the recruitment and activation of PI3K and AKT at the cell membrane, thereby regulating capillary stability and cell survival during angiogenesis [108]. Although these data suggest an inhibitory influence of ENG on EC migration, Jin and colleagues have demonstrated that ENG controls EC migration during vessel remodeling by modulating vascular endothelial growth factor (VEGF)-A-induced VEGF receptor (VEGFR)-2 signaling in a cell autonomous manner [109]. Therefore, future efforts should clarify and integrate the multiple roles of ENG in the regulation of EC behavior and angiogenesis.

Among its other roles in ECs, ENG mediates nitric oxide (NO)-dependent vasodilatation by regulating endothelial nitric oxide synthase (eNOS) expression in a TGF $\beta$ / ALK5/ SMAD2 dependent manner [110,111]. Moreover, via its RGD motif, endothelial ENG binds to integrins on vascular mural cells $(\alpha 5 \beta 1)$ [112], leukocytes $(\alpha 5 \beta 1)$ [14] and platelets $(\alpha 5 \beta 1, \alpha \mathrm{IIb} \beta 3)$ [113], thereby favoring the adhesion of these cells to the endothelium. In this context, ENG stabilizes endothelial barrier function through its interaction with cell adhesion proteins (e.g., Ras homolog family member A (RhoA) protein) [114].

Recently, new roles for ENG have been described in physiological contexts. For instance, ENG is necessary to maintain correct hair follicle cycling and proper stimulation of hair follicle stem cell niches [115]. Furthermore, ENG mediates the regulation of the thermogenic gene program of beige adipocytes [116].

To date, most of the studies on ENG have focused on the predominant L-ENG isoform [5]. However, there is evidence that S-ENG plays an equally important role in endothelial and myeloid senescence [20-22].

Altogether, this information expands our knowledge of ENG and suggests that the last word about the physiological role of this protein has not yet been written.

\section{Role of Endoglin on Tumor Cell Behavior}

ENG is involved in a series of processes that directly affect tumor cell behavior [117]. Besides ENG expression in tumor vessels, some neoplasms also present high levels of ENG in tumor cells, including melanoma, renal cell carcinoma (RCC), leukemias, certain subtypes of sarcomas, and breast, ovarian, endometrial, and prostate cancer [117-124]. The role of ENG in tumor cells depends on the cell context, in some cases promoting tumor development and progression, and playing an important role in oncogenic signaling, 
whereas in other cases it has been associated with tumor suppression [117]. Below, we firstly summarize the recent evidence suggesting that ENG acts as a tumor promoter followed by data supporting that ENG might play a tumor suppressive role in some cancer types.

ENG mainly regulates malignant phenotypes of cancer cells by modulating TGF $\beta$ /BMP signaling, yet it also acts through other SMAD-independent mechanisms [125]. Indeed, by promoting BMP signaling or by activating focal adhesion kinase (FAK) and PI3K pathways, ENG induces tumor plasticity in both Ewing sarcoma and melanoma [118]. Accordingly, ENG downregulation hinders invasiveness and abrogates tumor growth in preclinical models of Ewing sarcoma and melanoma [118]. Likewise, ENG promotes the epithelialmesenchymal transition, and it stimulates spheroid formation and the migratory abilities of pancreatic cancer cells $[126,127]$. Indeed, RNA interference (iRNA)-based and competitive inhibitor-based blocking of ENG induces the differentiation of pancreatic cancer cells and reduces their tumorigenicity in vivo [128]. Moreover, this ENG inhibition sensitizes tumor cells to gemcitabine, a conventional chemotherapeutic drug [128].

In line with these data, several studies have reported an important role for ENG in tumor malignancy and resistance to therapy. In fact, an ENG-positive subpopulation in RCC xenografts possesses self-renewal ability, contributing to in vivo tumorigenicity and chemoresistance to gemcitabine [129]. Similarly, ENG expression is associated with drug resistance, poor differentiation, advanced disease stage, and a high rate of recurrence in ovarian cancer patients [130]. Consequently, ENG inhibition with small interfering RNA (siRNA) in ovarian cancer cells produces a less aggressive phenotype, with the induction of apoptosis and enhanced sensitivity to carboplatin in in vivo models [131]. Moreover, the TRC105 anti-ENG antibody inhibits metastatic spread, thereby improving overall survival (OS) in animal models of high-grade serous ovarian cancer [132]. Interestingly, high levels of ENG are also correlated with poor OS and progression free survival (PFS) in acute myeloid leukemia [133].

ENG is also upregulated in prostate cancer cells upon radiation and it promotes resistance to treatment [134]. Indeed, ENG mediates the DNA damage response and the metabolic adaptations to stress caused by irradiation by regulating its downstream target sirtuin 1 (SIRT1) [134]. Consequently, in synergy with radiation, TRC105 significantly reduces tumor growth in prostate cancer xenograft models [134].

Despite the evidence described above, ENG also plays an important role as tumor suppressor in certain cancer types. In fact, ENG suppresses prostate cancer cell migration and invasion via the ALK2/SMAD1 pathway, and it inhibits tumor growth and metastasis in vivo, suggesting that ENG is a negative regulator of prostate cancer [135-139]. In addition, ENG gene methylation was associated with the lack of ENG in human breast tumors and a poor clinical outcome [140]. Moreover, ENG overexpression in MDA-MB231 breast cancer cells impaired migration and invasion, and reduced lung metastasis in vivo [140]. Furthermore, silencing of the ENG gene by epigenetic regulation appears to be a frequent event in both lung cancer and esophageal squamous cell carcinoma [119,141]. This lack of ENG expression was associated with a more invasive phenotype, supporting the role of ENG as a cell invasion- and tumor-suppressor gene in these cancer types [119,141].

All these data reveal that role of ENG in tumor cell behavior is dependent on cell context and must be exploited individually for each cancer.

\section{Impact on the Tumor Microenvironment}

\subsection{Role of Endoglin in the Tumor Microenvironment}

The tumor microenvironment (TME) plays a crucial role in cancer initiation and progression, a milieu that it is comprised of different cell types, including MSCs, fibroblasts, ECs, vascular cells, and immune cells [142]. The dynamic interplay between nonmalignant cells and primary neoplastic cells is now well established, which contributes to tumor-stroma co-evolution and favors tumor promotion and metastasis [142-144]. ENG is present in some cell types that comprise the TME (e.g., ECs, MSCs, cancer-associated 
fibroblasts (CAFs), immune cells), actively regulating their behavior during tumorigenesis (Figure 2) [143].
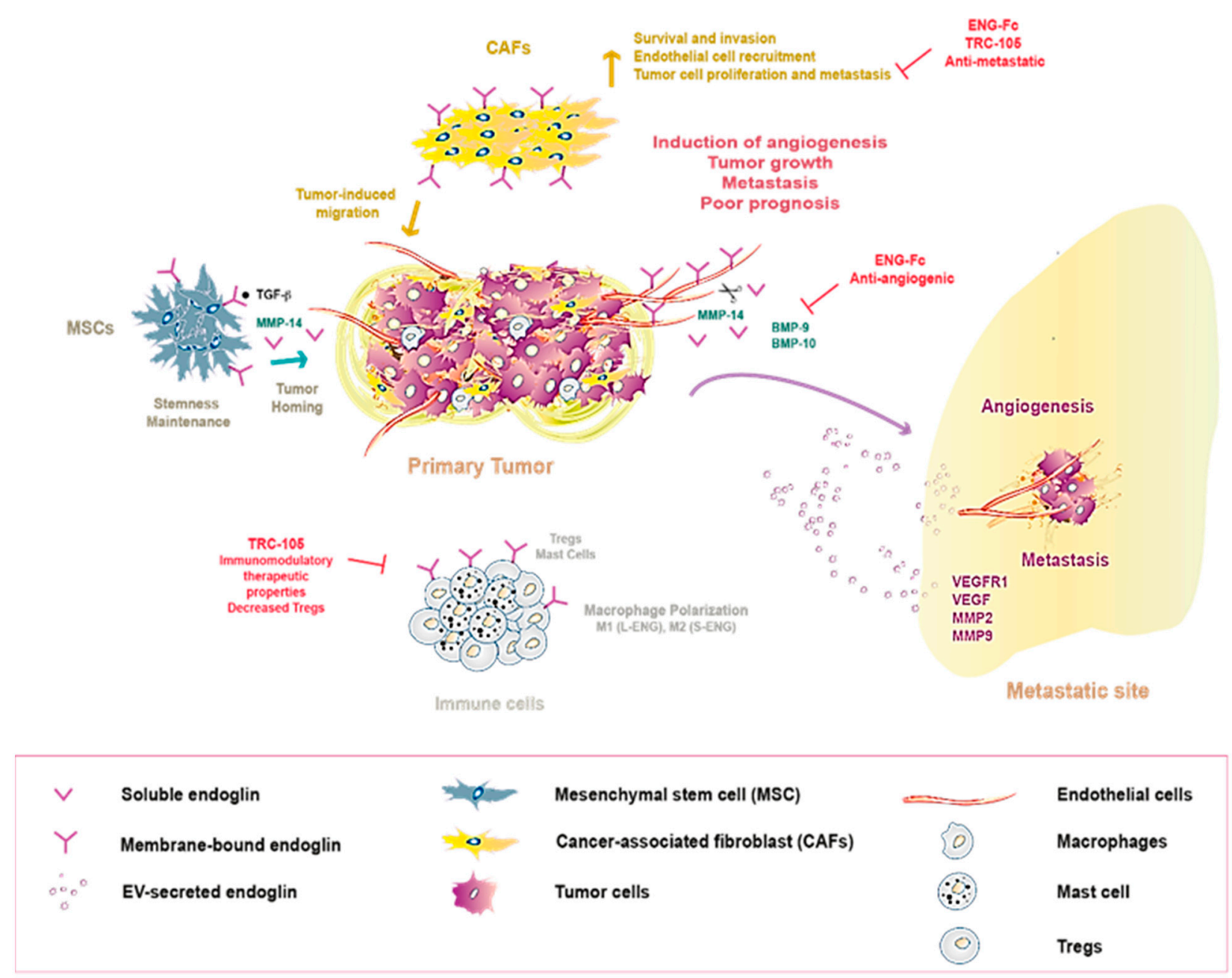

Figure 2. Endoglin acting in communication within the tumor microenvironment. Membrane-bound endoglin expression by several cell types within the tumor microenvironment (e.g., CAFs, macrophages, immune, and endothelial cells) and how its secretion (either soluble and/or in EVs) contributes to tumor progression and metastasis in different cancer models, making it a promising target for therapeutic strategies. Transforming growth factor $\beta$ (TGF $\beta$ ), bone morphogenic protein (BMP), matrix metalloproteinase 14 (MMP14), regulatory T cells (Tregs), extracellular vesicle (EV).

As discussed above, ENG expression is specifically upregulated in actively proliferating ECs of tumor-associated vessels in different types of cancer, which has led to the use of ENG as a marker for tumor angiogenesis $[124,145]$. Accordingly, when ENG expression reflects a high intratumoral microvessel density (IMVD), this is closely correlated with a poor prognosis in pediatric adrenocortical tumors, pediatric rhabdomyosarcoma, astrocytomas and glioblastomas, hepatocellular (HCC) and oral squamous cell carcinomas, as well as in breast, lung, prostate, colorectal (CRC), ovarian, gastric, endometrial, esophageal, and head and neck and renal cancers [145-147]. Recently, a potential mechanism was proposed by which high endothelial ENG expression may be associated with a worse outcome of different solid tumor types [148]. It was shown that continuous ENG overexpression in mice promotes EC activation and triggers angiogenesis, although it impedes vessel stabilization and maturation, giving rise to more permeable vessels [148]. These alterations facilitate the intravasation of tumor cells and the subsequent development of metastases, leading to a poorer cancer prognosis [148]. 
There is significant evidence that ENG is an interesting target to block tumor angiogenesis. ENG downregulation inhibits the proliferation and angiogenesis of human ovarian carcinoma-derived ECs [149], and it decreases the number of tumor-associated vessels and the growth of mammary adenocarcinomas in vivo [150]. The growth of Lewis lung carcinoma xenografts is compromised in ENG haploinsufficient mice $\left(\mathrm{Eng}^{+/-}\right)$, in which tumor vascularization is dampened relative to their wild-type $\left(\mathrm{Eng}^{+/+}\right)$littermates (as measured by capillary density, hemoglobin content, and vascular cell adhesion molecule-1 (VCAM-1) expression), in association with reduced eNOS phosphorylation [151]. Similarly, allelic ENG deletion slightly enhances the frequency of tumorigenesis, but it produces smaller, less vascularized, and less metastatic tumors in the transgenic adenocarcinoma mouse prostate (TRAMP) model [152]. Conversely, Anderberg and colleagues [153] showed that the ENG deficiency in mice (Eng ${ }^{+/-}$) facilitates tumor cell extravasation and increases metastatic spread. Although it is important to take into account that this model developed an HHT-like phenotype, which included vascular malformations and increased vascular permeability [153]. However, studies targeting ENG have mostly demonstrated good anti-angiogenic and anti-tumor effects to date $[117,154-156]$ as explained below.

As mentioned previously, ENG is also a marker of MSCs [48,157] (Figure 2), and it plays a crucial role in the maintenance of their stem-like properties [158,159]. Moreover, ENG stimulates the homing of BM-derived MSCs to different tumor types through TGF $\beta$ signaling, including glioma, HCC, and breast cancer [160-162]. At tumor sites, MSCs can support tumor development and metastasis in several types of cancer [162-165]. Indeed, human ENG-positive MSCs are strongly correlated with disease progression and poor prognosis in gastric cancer [166], although this remains controversial since, in some studies, a suppressive effect of MSCs on the growth of leukemia and HCC has also been reported $[167,168]$. Therefore, the influence of ENG expression in MSCs and their precise role in cancer progression needs to be further explored.

ENG is also present in CAFs (Figure 2), specifically located at invasive borders of human CRC tumors, as well as in their lymph nodes and liver metastases, suggesting a role for ENG-expressing CAFs in CRC metastases [169]. In vitro experiments revealed that ENG is indispensable for BMP-9-induced signaling, and for CAF survival and invasion [169]. Moreover, ENG-expressing CAFs promote tumor cell invasion and metastasis in two pre-clinical (i.e., zebrafish and mouse) models of CRC metastasis [169]. Similarly, ENG is required for CAF viability and recruitment to prostate tumors [152]. Indeed, ENG expression in CAFs stimulates EC recruitment and proliferation of prostate cancer cells through a mechanism that involves secreted factors such as components of the insulin growth factor (IGF) signaling pathway [152]. In addition, a recent study showed that after androgen signaling deprivation therapy (ADT), ENG upregulation in a CAF population contributes to castration resistance-associated neuroendocrine differentiation of prostate tumor cells via a paracrine mechanism [170]. In keeping with these data, ENG targeting using the TRC105 anti-ENG antibody or an ENG ligand trap (ENG-Fc) significantly dampened metastatic spread in breast cancer mouse models, which was associated with a strong reduction in the CAF content of primary tumors [171]. Together, these findings further suggest ENG drives pro-tumoral and -metastatic behavior in CAFs, making it a potential target for CAF-directed therapy.

Some reports have shed light on the role of ENG on immune cells within the TME (Figure 2). ENG expression was detected in CD4+ T cells [172] and more specifically, ENG was seen to be expressed by a subset of CD4+ regulatory T cells (Tregs) in human and mouse CRC tumors [173]. Interestingly, the TRC105 significantly decreased the number of intratumoral Tregs in a CRC xenograft model, which contributed directly to its anti-tumor effects [173]. Similarly, treatment with TRC105 led to a significant decline in the number of Tregs in patients with metastatic urothelial carcinoma and castrationresistant prostate cancer [174,175], making Tregs a novel target for ENG targeted therapy. In addition, macrophages express ENG and require it to mediate their innate immune responses $[58,176,177]$. Remarkably, ENG can direct macrophages towards a tumor- 
inhibiting M1-like or tumor-promoting M2-like phenotype depending on the isoform expressed, L-ENG or S-ENG, respectively [21,178]. Further studies should be carried out to determine the predominant ENG isoform in the tumor-associated macrophages (TAMs) associated with different cancer types to clarify its precise contribution to an anti-tumor M1-like or pro-tumor M2-like phenotype. Recently, it was reported that ENG is expressed strongly in the cytoplasmic granules of human mast cells [67]. The intraclass correlation coefficient revealed that ENG is a reliable biomarker for these immune cells when compared with mast cell tryptase and toluidine blue [67]. Consequently, ENG may be involved in the pathogenic processes associated with mast cells and it may be useful in their diagnosis. Mast cells play an important role in modulating the TME and thus, in mediating tumor progression [179]. However, the function of ENG in tumor-associated mast cells has yet to be established.

In conjunction, these findings demonstrate that ENG expression in several cell types within the TME contributes to tumor progression and metastasis in different cancer models, making it a promising target for microenvironment-directed therapy (Figure 2). Recent data adds further support to this hypothesis [180], as targeting ENG-expressing cells in the TME (e.g., MSCs, TAMs, and ECs) significantly improves the efficacy of standard treatment with the anti-disialoganglioside GD2 antibody dinutuximab combined with activated natural killer cells against high-risk neuroblastomas [180].

\subsection{Local and Distant Intercellular Communication by Secreted Endoglin (Exosomes and Soluble Endoglin)}

Accumulating evidence reveals that tumors can communicate with their microenvironment through the secretion of specific molecules [181]. These secreted factors promote molecular and cellular changes in both neoplastic and TME cells, favoring tumor growth, pre-metastatic niche formation, and, ultimately, metastasis [181,182]. Soluble factors have been widely described as key players in this crosstalk [181].

A soluble form of ENG (Sol-ENG) has been identified that results from the shedding of the extracellular domain of membrane-associated ENG due to the activity of the matrix metalloproteinase (MMP)-14 [183]. Evidence suggests an anti-angiogenic function for Sol-ENG in cancer and, indeed, the ENG extracellular domain fused to an immunoglobulin Fc domain (ENG-Fc) that mimics Sol-ENG reduces in vitro and in vivo angiogenesis and inhibits tumor growth in a xenograft model of CRC $[33,183]$ (Figure 2). This ENG-Fc binds specifically, and with high affinity to the TGF $\beta$ family ligands, BMP-9 and BMP-10, thereby blocking their downstream signaling [33]. In line with these data, ENG shedding appears to be an important mechanism by which TRC105 inhibits angiogenesis, as this anti-ENG antibody couples ENG to MMP14 in a complex at the cell surface, driving the release of the Sol-ENG anti-angiogenic factor [184].

So far, only a few in vitro studies have explored the involvement of Sol-ENG in cellto-cell communication in cancer. Sol-ENG has been implicated in active crosstalk between BM-MSCs and breast cancer cells [185]. In this process, TGF $\beta 1$ secreted by malignant breast cancer cells acts through a paracrine mechanism on BM-MSCs to induce the production of soluble MMP14 [185]. In turn, the proteolytic activity of MMP14 releases the ENG at the breast cancer cell membrane, promoting their migratory potential by upregulating the SMAD2/3 pathway [185]. Along similar lines, BM-MSC-derived Sol-ENG protects myeloma cells from BMP-9-induced apoptosis [186]. The role of Sol-ENG in cancer is therefore controversial, since it seems to be involved in the inhibition of tumor-associated angiogenesis but also in activities that promote a malignant phenotype in myeloma and breast cancer cells. Moreover, elevated levels of Sol-ENG are correlated with poor prognosis in some cancer patients $[187,188]$ as described below (Figure 2). Therefore, future studies should aim to elucidate the pro- or anti-tumoral effects of Sol-ENG on tumor-stroma crosstalk in different tumor types.

In addition to soluble factors, extracellular vesicles (EVs), such as exosomes (small EVS, 30-100 $\mathrm{nm}$ in size) and microvesicles (MVs, large EVs), are emerging as important mediators of TME communication $[189,190]$. Tumor-derived EVs contain biological information 
(RNA, DNA, proteins) from the primary tumor, and they can exert a functional influence once taken up by target cells, thereby modulating the TME and creating pre-metastatic niches, favorable microenvironments for metastasis to develop [190]. ENG-expressing MVs have been reported to participate in the induction of a pro-angiogenic and pro-metastatic microenvironment in human renal cancer [191] (Figure 2). These authors showed that ENG-expressing MVs derived from human renal cancer stem cells induce in vitro and in vivo angiogenesis, enhancing the organization, invasion, and resistance to apoptosis of ECs [191]. Moreover, these ENG-positive vesicles promote lung metastasis by upregulating the expression of different factors (VEGFR1, VEGF, MMP-2, MMP-9) that stimulate premetastatic niche formation in the lung [191] (Figure 2).

In this context, Yang and colleagues [192] demonstrated a mutual exchange of molecules between different MSC populations and tumor cells. More specifically, they showed that co-culture with ENG-expressing MSCs induces ovarian cancer and small cell hypercalcemic ovarian carcinoma-derived cells to acquire ENG, cells that barely express basal ENG [192]. These changes could occur through different mechanisms, such as exosome secretion and their subsequent cellular uptake [192]. However, the role of EV-secreted ENG is still not well understood and further studies in other tumor types should be performed to analyze the different molecular mechanisms through which ENG-expressing EVs could modulate the TME.

\section{Clinical Implications of Endoglin}

\subsection{State-of-the-Art Endoglin-Based Therapies}

As previously mentioned, ENG was initially described as a potent marker of angiogenesis [145], although in recent years it has also emerged as a promising drug target $[117,156,169,171,173-175]$. Therapies targeting ENG are based on evidence that this protein is mainly present in tissues undergoing some degree of repair or damage [193-195]. As described above, ENG is expressed strongly in proliferating ECs but also in cancer cells from different types of tumors $[118,120,121,123]$. Therefore, the generation of drugs to block this TGF $\beta$ co-receptor could represent an alternative anti-angiogenic and anti-tumor therapeutic strategy for neoplasms that are resistant to other anti-angiogenic agents (e.g., anti-VEGF) or chemotherapy.

The ENG-based therapies include the use of: (1) monoclonal antibodies; (2) antibody-drug conjugates (ADCs); (3) radiolabeled ENG antibodies; (4) ENG-based vaccines [117,175,196-205]. In general, the use of neutralizing monoclonal antibodies is an interesting therapeutic approach to target specific transmembrane receptors [206]. TRACON pharma developed the TRC105 monoclonal antibody, designed to block human ENG and to disrupt its activity as a TGF $\beta$ co-receptor, competing with BMP-9 [117]. Carotuximab (TRC105), induces antibodydependent cellular toxicity of angiogenic ECs and ENG-expressing tumor cells [117]. This drug is currently undergoing phase I/II/III clinical trials to treat RCC, prostate cancer, HCC, advanced angiosarcoma, non-small-cell lung cancer, ovarian cancer, and glioblastoma as well as other advanced cancers [175,196,197,203,207]. Notably, anti-VEGF therapies, such as bevacizumab, specifically target VEGF and block angiogenesis [208]. However, cells can become resistant to this therapy in hypoxic conditions by switching to VEGF-independent angiogenesis through ENG overexpression $[171,209]$. Therefore, TRC105 could help to sensitize these tumors resistant to VEGF inhibition.

Clinically, the first in-human study with TRC105 was carried out on 50 patients with advanced refractory disease including sarcoma and CRC, prostate, renal, lung, breast and ovarian cancer [200]. No adverse events (AEs) were generally associated with this therapy and the drug was tolerated at a dose of $10 \mathrm{mg} / \mathrm{kg} /$ week or $15 \mathrm{mg} / \mathrm{kg}$ every two weeks [200]. This therapy was especially effective in one case of castrate-resistant prostate cancer and another patient with metastatic uterine-carcinosarcoma [200]. A reduction in cancer antigen (CA)-125 levels was also observed in ovarian cancer patients [200]. Moreover, the evaluation of circulating biomarkers associated with angiogenesis in serum samples from patients showed that TRC105 modulated the levels of VEGF and Sol-ENG [200]. 
The use of TRC105 was also studied in a phase II trial involving HCC patients who had progressed following prior treatment with the anti-angiogenic tyrosine kinase inhibitor, sorafenib [196]. Toxicity was acceptable with epistaxis and headaches as the most common AEs [196]. Unfortunately, TRC105 did not exhibit an appreciable clinical response in these patients when used as a single agent [196]. Thus, efforts have focused on the use of TRC105 in different combinations to increase efficacy and prevent resistance. A phase $\mathrm{Ib}$ study tested the combination of TRC105 with the anti-VEGF antibody bevacizumab in a total of 38 patients including: one esthesioneuroblastoma, 2HCC, 17 CRC, 11 ovarian, two renal, two lung, one cervical, one endometrial, and one peritoneal cancer [198]. The combination therapy was well tolerated and exhibited promising efficacy with partial responses (PRs) and stable disease (SD) in 45\% of patients, 10 of whom had progressed after previous treatment with anti-VEGF monotherapy [198]. Interestingly, the evaluation of soluble biomarkers showed an increase in Sol-ENG and modulation of TGF $\beta 1$ in patients treated with TRC105 [200]. Patients with a clinical response (SD/PR) had low basal levels of ECM proteins like epithelial cadherin (E-cadherin), intercellular adhesion molecule 1 (ICAM-1) and osteopontin (OPN) after 3 weeks of treatment, as detected by enzyme-linked immunosorbent assay (ELISA) in plasma from CRC, ovarian, HCC, renal, lung, cervical, endometrial, neuroblastoma, and peritoneal cancer patients [200].

The combination of TRC105 with some small molecule inhibitors of VEGF has also been explored. For example, TRC105 in combination with sorafenib was evaluated in a phase I/II clinical trial including 25 patients with HCC [207]. This study was supported by pre-clinical data showing that resistance to sorafenib was associated with upregulation of ENG and that the addition of TRC105 to sorafenib led to enhanced tumor growth inhibition in preclinical models [207]. Results from this trial revealed that the combination was well-tolerated and was associated with promising outcomes, with an overall response rate (ORR) of 21\% [207]. Increases in serum Sol-ENG were observed following TRC105 treatment as demonstrated elsewhere [207]. An initial phase $\mathrm{Ib} / \mathrm{IIa}$ trial investigated the combination of TRC105 with pazopanib in patients with advanced soft tissue sarcoma, five of whom had angiosarcoma [210]. Angiosarcoma is a rare and aggressive endothelial tumor with poor prognosis [211]. Therapies targeting VEGF and other endothelial-related proteins have shown some promising results in combatting this tumor type [211]. There was preliminary evidence of clinical activity of combined TRC105/pazopanib treatment in 2/5 patients [210]. Given these encouraging results, a multicenter phase III trial exploring the efficacy of TRC105/pazopanib in patients with advanced angiosarcoma was set-up and is ongoing at the time of writing (TAPPAS: NCT02979899) [6]. Moreover, the combination of TRC105 and the VEGFR inhibitor axitinib was evaluated in a phase $\mathrm{Ib}$ trial involving patients with metastatic renal cell carcinoma (mRCC) who were refractory to first-line treatments [212]. This combined therapy showed a favorable toxicity profile and led to promising responses with a PR of $29 \%$ [212]. This preliminary evidence of activity led to a multicenter phase II trial enrolling 150 mRCC patients, a trial that was ongoing at the time of this writing (NCT01806064) [7]. In addition, TRC105 is currently being tested in combination with chemotherapy (paclitaxel/carboplatin) or bevacizumab in a phase Ib trial involving non-squamous cell lung cancer patients (NCT02429843) [6]. Another trial evaluating the safety and efficacy of the combination of TRC105 with other chemotherapeutic agents (letrozole/everolimus) is currently ongoing on patients with advanced hormone receptor positive and human epidermal growth factor receptor 2 (HER2) negative breast cancer (NCT02520063) [5].

The generation of ADCs is a promising field with a wide variety of options. ADCs are composed of three parts: (1) an antibody, specifically designed to bind to a cell surface target, and to induce internalization and intracellular uptake; (2) a payload, a drug that will be liberated into the cytoplasm after receptor-mediated endocytosis; together bound by (3) a chemical linker that brings stability to the structure and that allows the drug to be released once it is internalized [206,213,214]. The major advantage of ADCs is their 
high specificity, as only cells expressing the targeted protein are those that are likely to incorporate the drug $[206,213,214]$.

Several studies indicate that anti-ENG ADCs may represent a promising clinical approach to effectively reduce tumor angiogenesis and/or induce cell death upon their binding to target-expressing tumor cells [214]. Our group has shown that treatment with anti-ENG ADCs strongly impaired tumor growth in Ewing sarcoma cell line-derived xenografts and patient-derived xenografts [215]. We found that anti-human ENG monoclonal antibodies alone had no effect on tumor growth [215]. Nonetheless, the conjugation of these antibodies to a cytolysin or nigrin B payload led to a dramatic reduction in tumor size and recurrence when compared to the chemotherapeutic agent irinotecan alone [215]. Notably, the expression of ENG was heterogeneous in human Ewing sarcoma neoplastic clinical samples, which stresses the need for a good screening procedure (ENG expression) in a clinical context [215].

Antibodies targeting ENG also represent an attractive strategy for imaging, specifically through their binding to active endothelium [201,202,216]. An interesting experiment explored the biodistribution of TRC105 conjugated with gold nanoparticles (AuNPs) in mice bearing ENG-expressing melanoma xenografts [201]. These immunoconjugates were taken up strongly and specifically by melanoma tumors, with preserved tumor contrast in positron emission tomography (PET) imaging [201]. Moreover, no major tracer accumulation was detected over time in non-specific organs [201]. Hence, this study supports the use of anti-ENG antibodies conjugated with AuNPs for cancer imaging and lays the basis for further theragnostic applications.

Finally, DNA vaccines encoding ENG have been reported to be useful in terms of immune system activation [204,217]. In 2006, it was shown how an oral DNA vaccine encoding ENG could suppress metastatic spread in the D2F2 breast carcinoma mouse model [217]. Treatment with the vaccine induced activation of antigen-presenting dendritic cells and CD8+ T cells against ENG-positive target cells [217]. The immune responses caused by the vaccine were proposed to halt metastatic dissemination by eliminating proliferating ECs in the tumor vasculature [217]. More recently, it was demonstrated that the combination of an ENG-based DNA vaccine with immunomodulatory agents, such as cyclophosphamide or interleukin (IL)-12, exerted potent prophylactic and therapeutic antitumor activity in mouse models of aggressive melanoma [204]. Interestingly, this therapy led to polarization of the TME with a reduction of Tregs and inhibition of angiogenesis [204].

\subsection{Soluble Endoglin, a Promising Biomarker in Liquid Biopsies}

As described previously, ENG can be shed from the cell membrane as Sol-ENG [183]. This soluble form of ENG has been detected in the plasma and other body fluids from patients with several types of solid tumors [187,188,218-220] or with myeloid hematopoietic malignancies [221]. High levels of Sol-ENG are correlated with poor survival, relapse, and metastatic disease in different types of cancer such as CRC, prostate, breast, and lung cancer $[187,188]$. Interestingly, the levels of Sol-ENG increase after treatment with TRC105 in cancer patients, which may reflect the direct anti-angiogenic effects of the drug [200]. These findings suggest that Sol-ENG could also be used as a biomarker of response to therapy. In this respect, it is important to remember that the role of Sol-ENG in cancer remains unclear, and that although its levels are correlated with poor outcomes, it has also been described to play an important role in the inhibition of tumor angiogenesis $[33,183]$. Therefore, more research is needed to clarify the effects of Sol-ENG in tumor cells and in the TME.

There is evidence that Sol-ENG also plays a relevant role in pre-eclampsia [222-225], a condition characterized by maternal hypertension and proteinuria, representing a major cause of maternal/fetal mortality [226]. In pre-eclampsia, excess circulating levels of antiangiogenic and pro-coagulation factors lead to placental endothelial dysfunction, vascular permeability and ischemia [226]. More specifically, Sol-ENG contributes to the manifestation of pre-eclampsia by blocking pro-angiogenic factors, inhibiting vessel formation, and 
increasing permeability [225]. Indeed, pregnant women with pre-eclampsia have significantly higher levels of Sol-ENG, which later revert to basal levels after birth [227]. Likewise, EVs expressing ENG have been proposed as circulating biomarkers for endothelial injury and pre-eclampsia [228,229].

\section{Conclusions}

In conclusion, our understanding of the function of ENG in tumor cells and in the TME has progressed in recent years. Besides being an important mediator of tumor cell behavior in several cancer types, there is increasing evidence of a crucial role for ENG in modulating the TME, making it favorable for tumor progression and metastatic spread. Thus, apart from classic anti-angiogenic drugs, anti-ENG therapies are emerging as a promising approach for multi-target directed cancer therapy. There are a growing number of clinical trials testing the combination of the TRC105 anti-human ENG antibody with standard therapies in different tumor types, including chemotherapeutic agents (paclitaxel or carboplatin) or VEGF inhibitors (bevacizumab, sorafenib, or pazopanib). Interestingly, preliminary evidence shows clinical activity of such combinations in several patients who were refractory to first-line treatments, suggesting that combination treatments could overcome resistance to therapy. Moreover, recent studies show that other ENG-based therapies like anti-ENG ADCs or DNA vaccines encoding ENG could represent potential therapeutic options for cancer patients, enhancing tumor cell specificity and immune system activation, respectively. Future research should aim to explore the precise contribution of ENG expression in specific cell types to tumor progression and metastatic spread using cell-type specific ENG knockout or overexpressing mouse models. To sum up, novel combinations of anti-ENG therapies with current first-line treatments should be tested in pre-clinical models with the goal of bringing these advances more rapidly to the clinic. This will require worldwide, well-designed clinical trials involving patients who are refractory to standard anti-angiogenic treatments.

Author Contributions: Conceptualization, all authors; writing —original draft preparation, T.G.M., A.T.A. and P.P.-C.; writing-review and editing, T.G.M., A.T.A., P.P.-C., H.P. and E.d.Á.; supervision, A.T.A., H.P. and E.d.Á.; funding acquisition, A.T.A., H.P. and E.d.Á. All authors have read and agreed to the published version of the manuscript.

Funding: The authors gratefully acknowledge the support of the following sources of funding: H.P. US Department of Defense (W81XWH-16-1-0131) and Fundación Proyecto Neurofibromatosis. T.G.M. is granted by a FPU PhD Fellowship (Ministry of Science, Innovation and Universities, Government of Spain). Retos-Colaboración RTC-2014-2102-1 and PI17-000464 from MINECO-FEDER; PAIDI P18-RT-735 to E.d.Á. and A.T.A.; Buesa Grant2019 to A.T.A. A.T.A. was granted a Juan de la Cierva Contract from MINECO.

Institutional Review Board Statement: Not applicable.

Informed Consent Statement: Not applicable.

Data Availability Statement: Not applicable.

Conflicts of Interest: The authors declare no conflict of interest.

\section{Abbreviations}

$\begin{array}{ll}\text { aa } & \text { Amino acids } \\ \text { ADCs } & \text { Antibody-drug conjugates } \\ \text { ADT } & \text { Androgen signaling deprivation therapy } \\ \text { AEs } & \text { Adverse events } \\ \text { AKT } & \text { Protein kinase B } \\ \text { ALK } & \text { Activin-like kinase } \\ \text { AuNPs } & \text { Gold nanoparticles } \\ \text { BM } & \text { Bone marrow }\end{array}$




\begin{tabular}{|c|c|}
\hline BMP & Bone morphogenic protein \\
\hline CA & Cancer antigen \\
\hline CAF & Cancer-associated fibroblast \\
\hline Co-SMAD & Common partner SMAD \\
\hline CRC & Colorectal cancer \\
\hline Cys & Cysteine \\
\hline EC & Endothelial cell \\
\hline E-cadherin & Epithelial cadherin \\
\hline $\mathrm{ECM}$ & Extracellular matrix \\
\hline ELISA & Enzyme-linked immunosorbent assay \\
\hline ENG & Endoglin \\
\hline eNOS & Endothelial nitric oxide synthase \\
\hline ERK & Extracellular signal-regulated kinase \\
\hline EV & Extracellular vesicle \\
\hline F-actin & Filamentous-actin \\
\hline FAK & Focal adhesion kinase \\
\hline GAIP & G alpha interacting protein \\
\hline GDF & Growth differentiation factor \\
\hline GIPC & GAIP-interacting protein C-terminus \\
\hline $\mathrm{HCC}$ & Hepatocellular carcinoma \\
\hline HER2 & Human epidermal growth factor receptor 2 \\
\hline HHT & Hereditary hemorrhagic telangiectasia \\
\hline HSC & Hematopoietic stem cell \\
\hline ICAM-1 & Intercellular adhesion molecule 1 \\
\hline IGF & Insulin growth factor \\
\hline IL & Interleukin \\
\hline IMVD & Intratumoral microvessel density \\
\hline iRNA & RNA interference \\
\hline JNK & c-Jun N-terminal kinase \\
\hline MAPKs & Mitogen activated protein kinases \\
\hline MMP & Matrix metalloproteinase \\
\hline $\mathrm{mRCC}$ & Metastatic renal cell carcinoma \\
\hline mRNA & Messenger RNA \\
\hline MSC & Mesenchymal stem cell \\
\hline MVs & Microvesicles \\
\hline $\mathrm{NO}$ & Nitric oxide \\
\hline OPN & Osteopontin \\
\hline ORR & Overall response rate \\
\hline OS & Overall survival \\
\hline PDZ & PSD-95/Discs-large/ZO1 \\
\hline PET & Positron emission tomography \\
\hline PFS & Progression free survival \\
\hline PI3K & Phosphatidylinositol-3-kinase \\
\hline PR & Partial response \\
\hline RCC & Renal cell carcinoma \\
\hline RGD & Arginine-glycine-aspartic acid \\
\hline RhoA & Ras homolog family member A \\
\hline ROCK & Rho-associated coiled-coil kinase \\
\hline R-SMAD & Receptor-regulated SMAD \\
\hline SD & Stable disease \\
\hline Ser & Serine \\
\hline siRNA & Small interfering RNA \\
\hline SIRT1 & Sirtuin 1 \\
\hline SMA & Serine-methionine-alanine \\
\hline Sol-ENG & Soluble endoglin \\
\hline Sp1 & Specificity protein-1 \\
\hline TAM & Tumor-associated macrophage \\
\hline TGF $\beta$ & Transforming growth factor $\beta$ \\
\hline
\end{tabular}




$\begin{array}{ll}\text { TGF } \beta \text { RI } & \text { TGF } \beta \text { type-I receptor } \\ \text { TGF } \beta \text { RI } & \text { TGF } \beta \text { type-II receptor } \\ \text { Thr } & \text { Threonine } \\ \text { TME } & \text { Tumor microenvironment } \\ \text { TNF } \alpha & \text { Tumor necrosis factor } \alpha \\ \text { TRAMP } & \text { Transgenic adenocarcinoma mouse prostate } \\ \text { Treg } & \text { Regulatory T cell } \\ \text { VCAM-1 } & \text { Vascular cell adhesion molecule-1 } \\ \text { VEGF } & \text { Vascular endothelial growth factor } \\ \text { VEGFR } & \text { Vascular endothelial growth factor receptor } \\ \text { VSMC } & \text { Vascular smooth muscle cell } \\ \text { WNT } & \text { Wingless / Integrated } \\ \text { ZP } & \text { Zona pellucida } \\ \text { ZRP1 } & \text { Zyxin-related protein 1 }\end{array}$

\section{References}

1. Gougos, A.; Letarte, M. Identification of a human endothelial cell antigen with monoclonal antibody 44G4 produced against a pre-B leukemic cell line. J. Immunol. 1988, 141, 1925-1933. [PubMed]

2. Rius, C.; Smith, J.D.; Almendro, N.; Langa, C.; Botella, L.M.; Marchuk, D.A.; Vary, C.P.; Bernabeu, C. Cloning of the promoter region of human endoglin, the target gene for hereditary hemorrhagic telangiectasia type 1. Blood 1998, 92, 4677-4690. [CrossRef] [PubMed]

3. Botella, L.M.; Sanchez-Elsner, T.; Rius, C.; Corbi, A.; Bernabeu, C. Identification of a critical Sp1 site within the endoglin promoter and its involvement in the transforming growth factor-beta stimulation. J. Biol. Chem. 2001, 276, 34486-34494. [CrossRef]

4. Fernandez-Ruiz, E.; St-Jacques, S.; Bellon, T.; Letarte, M.; Bernabeu, C. Assignment of the human endoglin gene (END) to 9q34->qter. Cytogenet. Cell. Genet. 1993, 64, 204-207. [CrossRef] [PubMed]

5. Bellon, T.; Corbi, A.; Lastres, P.; Cales, C.; Cebrian, M.; Vera, S.; Cheifetz, S.; Massague, J.; Letarte, M.; Bernabeu, C. Identification and expression of two forms of the human transforming growth factor-beta-binding protein endoglin with distinct cytoplasmic regions. Eur. J. Immunol. 1993, 23, 2340-2345. [CrossRef] [PubMed]

6. Gougos, A.; Letarte, M. Primary structure of endoglin, an RGD-containing glycoprotein of human endothelial cells. J. Biol. Chem. 1990, 265, 8361-8364. [CrossRef]

7. Bork, P.; Sander, C. A large domain common to sperm receptors (Zp2 and Zp3) and TGF-beta type III receptor. FEBS Lett. 1992, 300, 237-240. [CrossRef]

8. Arai, H.; Hori, S.; Aramori, I.; Ohkubo, H.; Nakanishi, S. Cloning and expression of a cDNA encoding an endothelin receptor. Nature 1990, 348, 730-732. [CrossRef]

9. Alt, A.; Miguel-Romero, L.; Donderis, J.; Aristorena, M.; Blanco, F.J.; Round, A.; Rubio, V.; Bernabeu, C.; Marina, A. Structural and functional insights into endoglin ligand recognition and binding. PLoS ONE 2012, 7, e29948. [CrossRef]

10. Rossi, E.; Lopez-Novoa, J.M.; Bernabeu, C. Endoglin involvement in integrin-mediated cell adhesion as a putative pathogenic mechanism in hereditary hemorrhagic telangiectasia type 1 (HHT1). Front. Genet. 2014, 5, 457. [CrossRef] [PubMed]

11. Meurer, S.K.; Tihaa, L.; Lahme, B.; Gressner, A.M.; Weiskirchen, R. Identification of endoglin in rat hepatic stellate cells: New insights into transforming growth factor beta receptor signaling. J. Biol. Chem. 2005, 280, 3078-3087. [CrossRef]

12. Yamashita, H.; Ichijo, H.; Grimsby, S.; Moren, A.; ten Dijke, P.; Miyazono, K. Endoglin forms a heteromeric complex with the signaling receptors for transforming growth factor-beta. J. Biol. Chem. 1994, 269, 1995-2001. [CrossRef]

13. Meurer, S.K.; Alsamman, M.; Scholten, D.; Weiskirchen, R. Endoglin in liver fibrogenesis: Bridging basic science and clinical practice. World J. Biol. Chem. 2014, 5, 180-203. [CrossRef]

14. Rossi, E.; Sanz-Rodriguez, F.; Eleno, N.; Duwell, A.; Blanco, F.J.; Langa, C.; Botella, L.M.; Cabanas, C.; Lopez-Novoa, J.M.; Bernabeu, C. Endothelial endoglin is involved in inflammation: Role in leukocyte adhesion and transmigration. Blood 2013, 121, 403-415. [CrossRef]

15. Luo, B.H.; Carman, C.V.; Springer, T.A. Structural basis of integrin regulation and signaling. Annu. Rev. Immunol. 2007, 25, 619-647. [CrossRef] [PubMed]

16. Cheifetz, S.; Bellon, T.; Cales, C.; Vera, S.; Bernabeu, C.; Massague, J.; Letarte, M. Endoglin is a component of the transforming growth factor-beta receptor system in human endothelial cells. J. Biol. Chem. 1992, 267, 19027-19030. [CrossRef]

17. Lux, A.; Gallione, C.J.; Marchuk, D.A. Expression analysis of endoglin missense and truncation mutations: Insights into protein structure and disease mechanisms. Hum. Mol. Genet. 2000, 9, 745-755. [CrossRef] [PubMed]

18. Koleva, R.I.; Conley, B.A.; Romero, D.; Riley, K.S.; Marto, J.A.; Lux, A.; Vary, C.P. Endoglin structure and function: Determinants of endoglin phosphorylation by transforming growth factor-beta receptors. J. Biol. Chem. 2006, 281, 25110-25123. [CrossRef] [PubMed]

19. Lee, N.Y.; Ray, B.; How, T.; Blobe, G.C. Endoglin promotes transforming growth factor beta-mediated Smad $1 / 5 / 8$ signaling and inhibits endothelial cell migration through its association with GIPC. J. Biol. Chem. 2008, 283, 32527-32533. [CrossRef] 
20. Blanco, F.J.; Bernabeu, C. Alternative splicing factor or splicing factor-2 plays a key role in intron retention of the endoglin gene during endothelial senescence. Aging Cell 2011, 10, 896-907. [CrossRef]

21. Aristorena, M.; Blanco, F.J.; de Las Casas-Engel, M.; Ojeda-Fernandez, L.; Gallardo-Vara, E.; Corbi, A.; Botella, L.M.; Bernabeu, C. Expression of endoglin isoforms in the myeloid lineage and their role during aging and macrophage polarization. J. Cell Sci. 2014, 127, 2723-2735. [CrossRef]

22. Blanco, F.J.; Grande, M.T.; Langa, C.; Oujo, B.; Velasco, S.; Rodriguez-Barbero, A.; Perez-Gomez, E.; Quintanilla, M.; Lopez-Novoa, J.M.; Bernabeu, C. S-endoglin expression is induced in senescent endothelial cells and contributes to vascular pathology. Circ. Res. 2008, 103, 1383-1392. [CrossRef] [PubMed]

23. Gordon, K.J.; Blobe, G.C. Role of transforming growth factor-beta superfamily signaling pathways in human disease. Biochim. Biophys. Acta 2008, 1782, 197-228. [CrossRef]

24. Lebrin, F.; Goumans, M.J.; Jonker, L.; Carvalho, R.L.; Valdimarsdottir, G.; Thorikay, M.; Mummery, C.; Arthur, H.M.; ten Dijke, P. Endoglin promotes endothelial cell proliferation and TGF-beta/ALK1 signal transduction. EMBO J. 2004, 23, 4018-4028. [CrossRef]

25. Hata, A.; Chen, Y.G. TGF-beta Signaling from Receptors to Smads. Cold Spring Harb. Perspect. Biol. 2016, 8, a022061. [CrossRef] [PubMed]

26. Miyazono, K. TGF-beta signaling by Smad proteins. Cytokine Growth Factor Rev. 2000, 11, 15-22. [CrossRef]

27. Miyazono, K.; ten Dijke, P.; Heldin, C.H. TGF-beta signaling by Smad proteins. Adv. Immunol. 2000, 75, 115-157. [CrossRef] [PubMed]

28. Heldin, C.H.; Moustakas, A. Role of Smads in TGFbeta signaling. Cell Tissue Res. 2012, 347, 21-36. [CrossRef] [PubMed]

29. Mu, Y.; Gudey, S.K.; Landstrom, M. Non-Smad signaling pathways. Cell Tissue Res. 2012, 347, 11-20. [CrossRef] [PubMed]

30. Vander Ark, A.; Cao, J.; Li, X. TGF-beta receptors: In and beyond TGF-beta signaling. Cell. Signal. 2018, 52, 112-120. [CrossRef]

31. Barbara, N.P.; Wrana, J.L.; Letarte, M. Endoglin is an accessory protein that interacts with the signaling receptor complex of multiple members of the transforming growth factor-beta superfamily. J. Biol. Chem. 1999, 274, 584-594. [CrossRef]

32. David, L.; Mallet, C.; Mazerbourg, S.; Feige, J.J.; Bailly, S. Identification of BMP9 and BMP10 as functional activators of the orphan activin receptor-like kinase 1 (ALK1) in endothelial cells. Blood 2007, 109, 1953-1961. [CrossRef] [PubMed]

33. Castonguay, R.; Werner, E.D.; Matthews, R.G.; Presman, E.; Mulivor, A.W.; Solban, N.; Sako, D.; Pearsall, R.S.; Underwood, K.W.; Seehra, J.; et al. Soluble endoglin specifically binds bone morphogenetic proteins 9 and 10 via its orphan domain, inhibits blood vessel formation, and suppresses tumor growth. J. Biol. Chem. 2011, 286, 30034-30046. [CrossRef] [PubMed]

34. Guerrero-Esteo, M.; Sanchez-Elsner, T.; Letamendia, A.; Bernabeu, C. Extracellular and cytoplasmic domains of endoglin interact with the transforming growth factor-beta receptors I and II. J. Biol. Chem. 2002, 277, 29197-29209. [CrossRef] [PubMed]

35. Lastres, P.; Martin-Perez, J.; Langa, C.; Bernabeu, C. Phosphorylation of the human-transforming-growth-factor-beta-binding protein endoglin. Biochem. J. 1994, 301 Pt 3, 765-768. [CrossRef]

36. Li, D.Y.; Sorensen, L.K.; Brooke, B.S.; Urness, L.D.; Davis, E.C.; Taylor, D.G.; Boak, B.B.; Wendel, D.P. Defective angiogenesis in mice lacking endoglin. Science 1999, 284, 1534-1537. [CrossRef] [PubMed]

37. Bourdeau, A.; Dumont, D.J.; Letarte, M. A murine model of hereditary hemorrhagic telangiectasia. J. Clin. Investig. 1999, 104, 1343-1351. [CrossRef] [PubMed]

38. Rokhlin, O.W.; Cohen, M.B.; Kubagawa, H.; Letarte, M.; Cooper, M.D. Differential expression of endoglin on fetal and adult hematopoietic cells in human bone marrow. J. Immunol. 1995, 154, 4456-4465. [PubMed]

39. Cho, S.K.; Bourdeau, A.; Letarte, M.; Zuniga-Pflucker, J.C. Expression and function of CD105 during the onset of hematopoiesis from Flk1(+) precursors. Blood 2001, 98, 3635-3642. [CrossRef] [PubMed]

40. Zhang, L.; Magli, A.; Catanese, J.; Xu, Z.; Kyba, M.; Perlingeiro, R.C. Modulation of TGF-beta signaling by endoglin in murine hemangioblast development and primitive hematopoiesis. Blood 2011, 118, 88-97. [CrossRef]

41. Perlingeiro, R.C. Endoglin is required for hemangioblast and early hematopoietic development. Development 2007, 134, 3041-3048. [CrossRef]

42. Borges, L.; Iacovino, M.; Mayerhofer, T.; Koyano-Nakagawa, N.; Baik, J.; Garry, D.J.; Kyba, M.; Letarte, M.; Perlingeiro, R.C. A critical role for endoglin in the emergence of blood during embryonic development. Blood 2012, 119, 5417-5428. [CrossRef]

43. Borges, L.; Iacovino, M.; Koyano-Nakagawa, N.; Baik, J.; Garry, D.J.; Kyba, M.; Perlingeiro, R.C. Expression levels of endoglin distinctively identify hematopoietic and endothelial progeny at different stages of yolk sac hematopoiesis. Stem Cells 2013, 31, 1893-1901. [CrossRef] [PubMed]

44. Baik, J.; Magli, A.; Tahara, N.; Swanson, S.A.; Koyano-Nakagawa, N.; Borges, L.; Stewart, R.; Garry, D.J.; Kawakami, Y.; Thomson, J.A.; et al. Endoglin integrates BMP and Wnt signalling to induce haematopoiesis through JDP2. Nat. Commun. 2016, 7, 13101. [CrossRef] [PubMed]

45. Arthur, H.M.; Ure, J.; Smith, A.J.; Renforth, G.; Wilson, D.I.; Torsney, E.; Charlton, R.; Parums, D.V.; Jowett, T.; Marchuk, D.A.; et al. Endoglin, an ancillary TGFbeta receptor, is required for extraembryonic angiogenesis and plays a key role in heart development. Dev. Biol. 2000, 217, 42-53. [CrossRef] [PubMed]

46. Qu, R.; Silver, M.M.; Letarte, M. Distribution of endoglin in early human development reveals high levels on endocardial cushion tissue mesenchyme during valve formation. Cell Tissue Res. 1998, 292, 333-343. [CrossRef] 
47. Moody, J.L.; Singbrant, S.; Karlsson, G.; Blank, U.; Aspling, M.; Flygare, J.; Bryder, D.; Karlsson, S. Endoglin is not critical for hematopoietic stem cell engraftment and reconstitution but regulates adult erythroid development. Stem Cells 2007, 25, 2809-2819. [CrossRef] [PubMed]

48. Dominici, M.; Le Blanc, K.; Mueller, I.; Slaper-Cortenbach, I.; Marini, F.; Krause, D.; Deans, R.; Keating, A.; Prockop, D.; Horwitz, E. Minimal criteria for defining multipotent mesenchymal stromal cells. The International Society for Cellular Therapy position statement. Cytotherapy 2006, 8, 315-317. [CrossRef] [PubMed]

49. Mancini, M.L.; Verdi, J.M.; Conley, B.A.; Nicola, T.; Spicer, D.B.; Oxburgh, L.H.; Vary, C.P. Endoglin is required for myogenic differentiation potential of neural crest stem cells. Dev. Biol. 2007, 308, 520-533. [CrossRef] [PubMed]

50. Ishibashi, O.; Ikegame, M.; Takizawa, F.; Yoshizawa, T.; Moksed, M.A.; Iizawa, F.; Mera, H.; Matsuda, A.; Kawashima, H. Endoglin is involved in BMP-2-induced osteogenic differentiation of periodontal ligament cells through a pathway independent of Smad-1/5/8 phosphorylation. J. Cell. Physiol. 2010, 222, 465-473. [CrossRef] [PubMed]

51. Fan, W.; Li, J.; Wang, Y.; Pan, J.; Li, S.; Zhu, L.; Guo, C.; Yan, Z. CD105 promotes chondrogenesis of synovium-derived mesenchymal stem cells through Smad2 signaling. Biochem. Biophys. Res. Commun. 2016, 474, 338-344. [CrossRef]

52. Jin, H.J.; Park, S.K.; Oh, W.; Yang, Y.S.; Kim, S.W.; Choi, S.J. Down-regulation of CD105 is associated with multi-lineage differentiation in human umbilical cord blood-derived mesenchymal stem cells. Biochem. Biophys. Res. Commun. 2009, 381, 676-681. [CrossRef] [PubMed]

53. Mohsen-Kanson, T.; Hafner, A.L.; Wdziekonski, B.; Villageois, P.; Chignon-Sicard, B.; Dani, C. Expression of cell surface markers during self-renewal and differentiation of human adipose-derived stem cells. Biochem. Biophys. Res. Commun. 2013, 430, 871-875. [CrossRef] [PubMed]

54. Gougos, A.; St Jacques, S.; Greaves, A.; O'Connell, P.J.; d'Apice, A.J.; Buhring, H.J.; Bernabeu, C.; van Mourik, J.A.; Letarte, M. Identification of distinct epitopes of endoglin, an RGD-containing glycoprotein of endothelial cells, leukemic cells, and syncytiotrophoblasts. Int. Immunol. 1992, 4, 83-92. [CrossRef]

55. St-Jacques, S.; Forte, M.; Lye, S.J.; Letarte, M. Localization of endoglin, a transforming growth factor-beta binding protein, and of CD44 and integrins in placenta during the first trimester of pregnancy. Biol. Reprod. 1994, 51, 405-413. [CrossRef] [PubMed]

56. Dagdeviren, A.; Muftuoglu, S.F.; Cakar, A.N.; Ors, U. Endoglin (CD 105) expression in human lymphoid organs and placenta. Ann. Anat. 1998, 180, 461-469. [CrossRef]

57. Buhring, H.J.; Muller, C.A.; Letarte, M.; Gougos, A.; Saalmuller, A.; van Agthoven, A.J.; Busch, F.W. Endoglin is expressed on a subpopulation of immature erythroid cells of normal human bone marrow. Leukemia 1991, 5, 841-847.

58. Lastres, P.; Bellon, T.; Cabanas, C.; Sanchez-Madrid, F.; Acevedo, A.; Gougos, A.; Letarte, M.; Bernabeu, C. Regulated expression on human macrophages of endoglin, an Arg-Gly-Asp-containing surface antigen. Eur. J. Immunol. 1992, 22, 393-397. [CrossRef]

59. Robledo, M.M.; Hidalgo, A.; Lastres, P.; Arroyo, A.G.; Bernabeu, C.; Sanchez-Madrid, F.; Teixido, J. Characterization of TGF-beta 1-binding proteins in human bone marrow stromal cells. Br. J. Haematol. 1996, 93, 507-514. [CrossRef] [PubMed]

60. Adam, P.J.; Clesham, G.J.; Weissberg, P.L. Expression of endoglin mRNA and protein in human vascular smooth muscle cells. Biochem. Biophys. Res. Commun. 1998, 247, 33-37. [CrossRef]

61. Barry, F.P.; Boynton, R.E.; Haynesworth, S.; Murphy, J.M.; Zaia, J. The monoclonal antibody SH-2, raised against human mesenchymal stem cells, recognizes an epitope on endoglin (CD105). Biochem. Biophys. Res. Commun. 1999, 265, 134-139. [CrossRef] [PubMed]

62. St-Jacques, S.; Cymerman, U.; Pece, N.; Letarte, M. Molecular characterization and in situ localization of murine endoglin reveal that it is a transforming growth factor-beta binding protein of endothelial and stromal cells. Endocrinology 1994, 134, $2645-2657$. [CrossRef] [PubMed]

63. Rodriguez-Barbero, A.; Obreo, J.; Eleno, N.; Rodriguez-Pena, A.; Duwel, A.; Jerkic, M.; Sanchez-Rodriguez, A.; Bernabeu, C.; Lopez-Novoa, J.M. Endoglin expression in human and rat mesangial cells and its upregulation by TGF-beta1. Biochem. Biophys. Res. Commun. 2001, 282, 142-147. [CrossRef] [PubMed]

64. Pierelli, L.; Bonanno, G.; Rutella, S.; Marone, M.; Scambia, G.; Leone, G. CD105 (endoglin) expression on hematopoietic stem/progenitor cells. Leuk. Lymphoma 2001, 42, 1195-1206. [CrossRef] [PubMed]

65. Parker, W.L.; Goldring, M.B.; Philip, A. Endoglin is expressed on human chondrocytes and forms a heteromeric complex with betaglycan in a ligand and type II TGFbeta receptor independent manner. J. Bone Miner. Res. 2003, 18, 289-302. [CrossRef]

66. Quintanilla, M.; Ramirez, J.R.; Perez-Gomez, E.; Romero, D.; Velasco, B.; Letarte, M.; Lopez-Novoa, J.M.; Bernabeu, C. Expression of the TGF-beta coreceptor endoglin in epidermal keratinocytes and its dual role in multistage mouse skin carcinogenesis. Oncogene 2003, 22, 5976-5985. [CrossRef]

67. Trentin Brum, S.; Demasi, A.P.; Fantelli Stelini, R.; Cintra, M.L.; Cavalcanti de Araujo, V.; Borges Soares, A. Endoglin is Highly Expressed in Human Mast Cells. Appl. Immunohistochem. Mol. Morphol. 2019, 27, 613-617. [CrossRef]

68. Meurer, S.K.; Tihaa, L.; Borkham-Kamphorst, E.; Weiskirchen, R. Expression and functional analysis of endoglin in isolated liver cells and its involvement in fibrogenic Smad signalling. Cell. Signal. 2011, 23, 683-699. [CrossRef] [PubMed]

69. Robledo, M.M.; Ursa, M.A.; Sanchez-Madrid, F.; Teixido, J. Associations between TGF-beta1 receptors in human bone marrow stromal cells. Br. J. Haematol. 1998, 102, 804-811. [CrossRef]

70. Li, C.; Issa, R.; Kumar, P.; Hampson, I.N.; Lopez-Novoa, J.M.; Bernabeu, C.; Kumar, S. CD105 prevents apoptosis in hypoxic endothelial cells. J. Cell Sci. 2003, 116, 2677-2685. [CrossRef] 
71. Zhu, Y.; Sun, Y.; Xie, L.; Jin, K.; Sheibani, N.; Greenberg, D.A. Hypoxic induction of endoglin via mitogen-activated protein kinases in mouse brain microvascular endothelial cells. Stroke 2003, 34, 2483-2488. [CrossRef]

72. Chen, K.; Mehta, J.L.; Li, D.; Joseph, L.; Joseph, J. Transforming growth factor beta receptor endoglin is expressed in cardiac fibroblasts and modulates profibrogenic actions of angiotensin II. Circ. Res. 2004, 95, 1167-1173. [CrossRef]

73. Li, C.; Guo, B.; Ding, S.; Rius, C.; Langa, C.; Kumar, P.; Bernabeu, C.; Kumar, S. TNF alpha down-regulates CD105 expression in vascular endothelial cells: A comparative study with TGF beta 1. Anticancer Res. 2003, 23, 1189-1196.

74. Pece-Barbara, N.; Vera, S.; Kathirkamathamby, K.; Liebner, S.; Di Guglielmo, G.M.; Dejana, E.; Wrana, J.L.; Letarte, M. Endoglin null endothelial cells proliferate faster and are more responsive to transforming growth factor beta1 with higher affinity receptors and an activated Alk1 pathway. J. Biol. Chem. 2005, 280, 27800-27808. [CrossRef] [PubMed]

75. Pomeraniec, L.; Hector-Greene, M.; Ehrlich, M.; Blobe, G.C.; Henis, Y.I. Regulation of TGF-beta receptor hetero-oligomerization and signaling by endoglin. Mol. Biol. Cell 2015, 26, 3117-3127. [CrossRef] [PubMed]

76. Westphal, J.R.; Willems, H.W.; Schalkwijk, C.J.; Ruiter, D.J.; de Waal, R.M. A new 180-kDa dermal endothelial cell activation antigen: In vitro and in situ characteristics. J. Investig. Dermatol. 1993, 100, 27-34. [CrossRef]

77. Burrows, F.J.; Derbyshire, E.J.; Tazzari, P.L.; Amlot, P.; Gazdar, A.F.; King, S.W.; Letarte, M.; Vitetta, E.S.; Thorpe, P.E. Up-regulation of endoglin on vascular endothelial cells in human solid tumors: Implications for diagnosis and therapy. Clin. Cancer Res. 1995, 1, $1623-1634$.

78. Thorpe, P.E.; Burrows, F.J. Antibody-directed targeting of the vasculature of solid tumors. Breast Cancer Res. Treat. 1995, 36, 237-251. [CrossRef] [PubMed]

79. Wang, J.M.; Kumar, S.; van Agthoven, A.; Kumar, P.; Pye, D.; Hunter, R.D. Irradiation induces up-regulation of E9 protein (CD105) in human vascular endothelial cells. Int. J. Cancer 1995, 62, 791-796. [CrossRef] [PubMed]

80. Miller, D.W.; Graulich, W.; Karges, B.; Stahl, S.; Ernst, M.; Ramaswamy, A.; Sedlacek, H.H.; Muller, R.; Adamkiewicz, J. Elevated expression of endoglin, a component of the TGF-beta-receptor complex, correlates with proliferation of tumor endothelial cells. Int. J. Cancer 1999, 81, 568-572. [CrossRef]

81. Kumar, P.; Wang, J.M.; Bernabeu, C. CD 105 and angiogenesis. J. Pathol. 1996, 178, 363-366. [CrossRef]

82. Warrington, K.; Hillarby, M.C.; Li, C.; Letarte, M.; Kumar, S. Functional role of CD105 in TGF-beta1 signalling in murine and human endothelial cells. Anticancer Res. 2005, 25, 1851-1864. [PubMed]

83. Pece-Barbara, N.; Cymerman, U.; Vera, S.; Marchuk, D.A.; Letarte, M. Expression analysis of four endoglin missense mutations suggests that haploinsufficiency is the predominant mechanism for hereditary hemorrhagic telangiectasia type 1. Hum. Mol. Genet. 1999, 8, 2171-2181. [CrossRef] [PubMed]

84. McAllister, K.A.; Grogg, K.M.; Johnson, D.W.; Gallione, C.J.; Baldwin, M.A.; Jackson, C.E.; Helmbold, E.A.; Markel, D.S.; McKinnon, W.C.; Murrell, J.; et al. Endoglin, a TGF-beta binding protein of endothelial cells, is the gene for hereditary haemorrhagic telangiectasia type 1. Nat. Genet. 1994, 8, 345-351. [CrossRef] [PubMed]

85. Chung, M.G. Hereditary hemorrhagic telangiectasia. Handb. Clin. Neurol. 2015, 132, 185-197. [CrossRef] [PubMed]

86. Finnson, K.W.; Parker, W.L.; Chi, Y.; Hoemann, C.D.; Goldring, M.B.; Antoniou, J.; Philip, A. Endoglin differentially regulates TGF-beta-induced Smad2/3 and Smad1/5 signalling and its expression correlates with extracellular matrix production and cellular differentiation state in human chondrocytes. Osteoarthritis Cartilage 2010, 18, 1518-1527. [CrossRef]

87. Guo, B.; Slevin, M.; Li, C.; Parameshwar, S.; Liu, D.; Kumar, P.; Bernabeu, C.; Kumar, S. CD105 inhibits transforming growth factor-beta-Smad3 signalling. Anticancer Res. 2004, 24, 1337-1345.

88. Scherner, O.; Meurer, S.K.; Tihaa, L.; Gressner, A.M.; Weiskirchen, R. Endoglin differentially modulates antagonistic transforming growth factor-beta1 and BMP-7 signaling. J. Biol. Chem. 2007, 282, 13934-13943. [CrossRef]

89. Li, C.; Hampson, I.N.; Hampson, L.; Kumar, P.; Bernabeu, C.; Kumar, S. CD105 antagonizes the inhibitory signaling of transforming growth factor beta1 on human vascular endothelial cells. FASEB J. 2000, 14, 55-64. [CrossRef] [PubMed]

90. Letamendia, A.; Lastres, P.; Botella, L.M.; Raab, U.; Langa, C.; Velasco, B.; Attisano, L.; Bernabeu, C. Role of endoglin in cellular responses to transforming growth factor-beta. A comparative study with betaglycan. J. Biol. Chem. 1998, 273, 33011-33019. [CrossRef] [PubMed]

91. Lastres, P.; Letamendia, A.; Zhang, H.; Rius, C.; Almendro, N.; Raab, U.; Lopez, L.A.; Langa, C.; Fabra, A.; Letarte, M.; et al. Endoglin modulates cellular responses to TGF-beta 1. J. Cell Biol. 1996, 133, 1109-1121. [CrossRef] [PubMed]

92. Burke, J.P.; Watson, R.W.; Mulsow, J.J.; Docherty, N.G.; Coffey, J.C.; O'Connell, P.R. Endoglin negatively regulates transforming growth factor beta1-induced profibrotic responses in intestinal fibroblasts. Br. J. Surg. 2010, 97, 892-901. [CrossRef]

93. Caniggia, I.; Taylor, C.V.; Ritchie, J.W.; Lye, S.J.; Letarte, M. Endoglin regulates trophoblast differentiation along the invasive pathway in human placental villous explants. Endocrinology 1997, 138, 4977-4988. [CrossRef] [PubMed]

94. Rodriguez-Barbero, A.; Obreo, J.; Alvarez-Munoz, P.; Pandiella, A.; Bernabeu, C.; Lopez-Novoa, J.M. Endoglin modulation of TGF-beta1-induced collagen synthesis is dependent on ERK1/2 MAPK activation. Cell. Physiol. Biochem. 2006, 18, 135-142. [CrossRef]

95. Guerrero-Esteo, M.; Lastres, P.; Letamendia, A.; Perez-Alvarez, M.J.; Langa, C.; Lopez, L.A.; Fabra, A.; Garcia-Pardo, A.; Vera, S.; Letarte, M.; et al. Endoglin overexpression modulates cellular morphology, migration, and adhesion of mouse fibroblasts. Eur. J. Cell Biol. 1999, 78, 614-623. [CrossRef]

96. Pericacho, M.; Velasco, S.; Prieto, M.; Llano, E.; Lopez-Novoa, J.M.; Rodriguez-Barbero, A. Endoglin haploinsufficiency promotes fibroblast accumulation during wound healing through Akt activation. PLoS ONE 2013, 8, e54687. [CrossRef] 
97. Perez-Gomez, E.; Jerkic, M.; Prieto, M.; Del Castillo, G.; Martin-Villar, E.; Letarte, M.; Bernabeu, C.; Perez-Barriocanal, F.; Quintanilla, M.; Lopez-Novoa, J.M. Impaired wound repair in adult endoglin heterozygous mice associated with lower NO bioavailability. J. Investig. Dermatol. 2014, 134, 247-255. [CrossRef] [PubMed]

98. Rivera, L.B.; Brekken, R.A. SPARC promotes pericyte recruitment via inhibition of endoglin-dependent TGF-beta1 activity. J. Cell Biol. 2011, 193, 1305-1319. [CrossRef]

99. Mano, Y.; Kotani, T.; Shibata, K.; Matsumura, H.; Tsuda, H.; Sumigama, S.; Yamamoto, E.; Iwase, A.; Senga, T.; Kikkawa, F. The loss of endoglin promotes the invasion of extravillous trophoblasts. Endocrinology 2011, 152, 4386-4394. [CrossRef] [PubMed]

100. Guo, B.; Rooney, P.; Slevin, M.; Li, C.; Parameshwar, S.; Liu, D.; Kumar, P.; Bernabeu, C.; Kumar, S. Overexpression of CD105 in rat myoblasts: Role of CD105 in cell attachment, spreading and survival. Int. J. Oncol. 2004, 25, 285-291. [CrossRef] [PubMed]

101. Tian, H.; Ketova, T.; Hardy, D.; Xu, X.; Gao, X.; Zijlstra, A.; Blobe, G.C. Endoglin Mediates Vascular Maturation by Promoting Vascular Smooth Muscle Cell Migration and Spreading. Arterioscler. Thromb. Vasc. Biol. 2017, 37, 1115-1126. [CrossRef]

102. Meurer, S.K.; Alsamman, M.; Sahin, H.; Wasmuth, H.E.; Kisseleva, T.; Brenner, D.A.; Trautwein, C.; Weiskirchen, R.; Scholten, D. Overexpression of endoglin modulates TGF-beta1-signalling pathways in a novel immortalized mouse hepatic stellate cell line. PLoS ONE 2013, 8, e56116. [CrossRef]

103. Conley, B.A.; Koleva, R.; Smith, J.D.; Kacer, D.; Zhang, D.; Bernabeu, C.; Vary, C.P. Endoglin controls cell migration and composition of focal adhesions: Function of the cytosolic domain. J. Biol. Chem. 2004, 279, 27440-27449. [CrossRef] [PubMed]

104. Young, K.; Tweedie, E.; Conley, B.; Ames, J.; FitzSimons, M.; Brooks, P.; Liaw, L.; Vary, C.P. BMP9 Crosstalk with the Hippo Pathway Regulates Endothelial Cell Matricellular and Chemokine Responses. PLoS ONE 2015, 10, e0122892. [CrossRef] [PubMed]

105. Sanz-Rodriguez, F.; Guerrero-Esteo, M.; Botella, L.M.; Banville, D.; Vary, C.P.; Bernabeu, C. Endoglin regulates cytoskeletal organization through binding to ZRP-1, a member of the Lim family of proteins. J. Biol. Chem. 2004, 279, 32858-32868. [CrossRef] [PubMed]

106. Lee, N.Y.; Blobe, G.C. The interaction of endoglin with beta-arrestin2 regulates transforming growth factor-beta-mediated ERK activation and migration in endothelial cells. J. Biol. Chem. 2007, 282, 21507-21517. [CrossRef] [PubMed]

107. Tian, H.; Mythreye, K.; Golzio, C.; Katsanis, N.; Blobe, G.C. Endoglin mediates fibronectin/alpha5beta1 integrin and TGF-beta pathway crosstalk in endothelial cells. EMBO J. 2012, 31, 3885-3900. [CrossRef] [PubMed]

108. Lee, N.Y.; Golzio, C.; Gatza, C.E.; Sharma, A.; Katsanis, N.; Blobe, G.C. Endoglin regulates PI3-kinase/Akt trafficking and signaling to alter endothelial capillary stability during angiogenesis. Mol. Biol. Cell 2012, 23, 2412-2423. [CrossRef]

109. Jin, Y.; Muhl, L.; Burmakin, M.; Wang, Y.; Duchez, A.C.; Betsholtz, C.; Arthur, H.M.; Jakobsson, L. Endoglin prevents vascular malformation by regulating flow-induced cell migration and specification through VEGFR2 signalling. Nat. Cell Biol. 2017, 19, 639-652. [CrossRef] [PubMed]

110. Jerkic, M.; Rivas-Elena, J.V.; Prieto, M.; Carron, R.; Sanz-Rodriguez, F.; Perez-Barriocanal, F.; Rodriguez-Barbero, A.; Bernabeu, C.; Lopez-Novoa, J.M. Endoglin regulates nitric oxide-dependent vasodilatation. FASEB J. 2004, 18, 609-611. [CrossRef] [PubMed]

111. Santibanez, J.F.; Letamendia, A.; Perez-Barriocanal, F.; Silvestri, C.; Saura, M.; Vary, C.P.; Lopez-Novoa, J.M.; Attisano, L.; Bernabeu, C. Endoglin increases eNOS expression by modulating Smad2 protein levels and Smad2-dependent TGF-beta signaling. J. Cell. Physiol. 2007, 210, 456-468. [CrossRef] [PubMed]

112. Rossi, E.; Smadja, D.M.; Boscolo, E.; Langa, C.; Arevalo, M.A.; Pericacho, M.; Gamella-Pozuelo, L.; Kauskot, A.; Botella, L.M.; Gaussem, P.; et al. Endoglin regulates mural cell adhesion in the circulatory system. Cell. Mol. Life Sci. 2016, 73, 1715-1739. [CrossRef] [PubMed]

113. Rossi, E.; Pericacho, M.; Bachelot-Loza, C.; Pidard, D.; Gaussem, P.; Poirault-Chassac, S.; Blanco, F.J.; Langa, C.; GonzalezManchon, C.; Novoa, J.M.L.; et al. Human endoglin as a potential new partner involved in platelet-endothelium interactions. Cell. Mol. Life Sci. 2018, 75, 1269-1284. [CrossRef] [PubMed]

114. Jerkic, M.; Letarte, M. Increased endothelial cell permeability in endoglin-deficient cells. FASEB J. 2015, 29, 3678-3688. [CrossRef]

115. Calvo-Sanchez, M.I.; Fernandez-Martos, S.; Carrasco, E.; Moreno-Bueno, G.; Bernabeu, C.; Quintanilla, M.; Espada, J. A role for the Tgf-beta/Bmp co-receptor Endoglin in the molecular oscillator that regulates the hair follicle cycle. J. Mol. Cell Biol. 2019, 11, 39-52. [CrossRef]

116. Higa, R.; Hanada, T.; Teranishi, H.; Miki, D.; Seo, K.; Hada, K.; Shiraishi, H.; Mimata, H.; Hanada, R.; Kangawa, K.; et al. CD105 maintains the thermogenic program of beige adipocytes by regulating Smad2 signaling. Mol. Cell. Endocrinol. 2018, 474, 184-193. [CrossRef]

117. Rosen, L.S.; Gordon, M.S.; Robert, F.; Matei, D.E. Endoglin for targeted cancer treatment. Curr. Oncol. Rep. 2014, 16, 365. [CrossRef] [PubMed]

118. Pardali, E.; van der Schaft, D.W.; Wiercinska, E.; Gorter, A.; Hogendoorn, P.C.; Griffioen, A.W.; ten Dijke, P. Critical role of endoglin in tumor cell plasticity of Ewing sarcoma and melanoma. Oncogene 2011, 30, 334-345. [CrossRef]

119. O'Leary, K.; Shia, A.; Cavicchioli, F.; Haley, V.; Comino, A.; Merlano, M.; Mauri, F.; Walter, K.; Lackner, M.; Wischnewsky, M.B.; et al. Identification of Endoglin as an epigenetically regulated tumour-suppressor gene in lung cancer. Br. J. Cancer 2015, 113, 970-978. [CrossRef]

120. Hara, H. Endoglin (CD105) and claudin-5 expression in cutaneous angiosarcoma. Am. J. Dermatopathol. 2012, 34, 779-782. [CrossRef]

121. Hughes, J.; Rokhlin, O.; Cohen, M. Endoglin (CD105) expression in non-neoplastic and neoplastic human tissues and human cancer cell lines. Oncol. Rep. 1996, 3, 379-383. [CrossRef] 
122. Oxmann, D.; Held-Feindt, J.; Stark, A.M.; Hattermann, K.; Yoneda, T.; Mentlein, R. Endoglin expression in metastatic breast cancer cells enhances their invasive phenotype. Oncogene 2008, 27, 3567-3575. [CrossRef] [PubMed]

123. Postiglione, L.; Di Domenico, G.; Caraglia, M.; Marra, M.; Giuberti, G.; Del Vecchio, L.; Montagnani, S.; Macri, M.; Bruno, E.M.; Abbruzzese, A.; et al. Differential expression and cytoplasm/membrane distribution of endoglin (CD105) in human tumour cell lines: Implications in the modulation of cell proliferation. Int. J. Oncol. 2005, 26, 1193-1201. [CrossRef]

124. Oplawski, M.; Dziobek, K.; Adwent, I.; Dabrus, D.; Grabarek, B.; Zmarzly, N.; Plewka, A.; Boron, D. Expression Profile of Endoglin in Different Grades of Endometrial Cancer. Curr. Pharm. Biotechnol. 2018, 19, 990-995. [CrossRef] [PubMed]

125. Perez-Gomez, E.; Del Castillo, G.; Juan Francisco, S.; Lopez-Novoa, J.M.; Bernabeu, C.; Quintanilla, M. The role of the TGF-beta coreceptor endoglin in cancer. ScientificWorldJournal 2010, 10, 2367-2384. [CrossRef]

126. Kokaji, E.; Shimomura, A.; Minamisaka, T.; Nakajima, T.; Miwa, S.; Hatta, H.; Nishida, T.; Kiya, C.; Imura, J. Endoglin (CD105) and SMAD4 regulate spheroid formation and the suppression of the invasive ability of human pancreatic cancer cells. Int. J. Oncol. 2018, 52, 892-900. [CrossRef] [PubMed]

127. Fujiwara, K.; Ohuchida, K.; Ohtsuka, T.; Mizumoto, K.; Shindo, K.; Ikenaga, N.; Cui, L.; Takahata, S.; Aishima, S.; Tanaka, M. Migratory activity of CD105+ pancreatic cancer cells is strongly enhanced by pancreatic stellate cells. Pancreas 2013, 42, 1283-1290. [CrossRef]

128. Pal, K.; Pletnev, A.A.; Dutta, S.K.; Wang, E.; Zhao, R.; Baral, A.; Yadav, V.K.; Aggarwal, S.; Krishnaswamy, S.; Alkharfy, K.M.; et al. Inhibition of endoglin-GIPC interaction inhibits pancreatic cancer cell growth. Mol. Cancer Ther. 2014, 13, 2264-2275. [CrossRef]

129. Hu, J.; Guan, W.; Liu, P.; Dai, J.; Tang, K.; Xiao, H.; Qian, Y.; Sharrow, A.C.; Ye, Z.; Wu, L.; et al. Endoglin Is Essential for the Maintenance of Self-Renewal and Chemoresistance in Renal Cancer Stem Cells. Stem Cell Rep. 2017, 9, 464-477. [CrossRef] [PubMed]

130. Zhang, J.; Yuan, B.; Zhang, H.; Li, H. Human epithelial ovarian cancer cells expressing CD105, CD44 and CD106 surface markers exhibit increased invasive capacity and drug resistance. Oncol. Lett. 2019, 17, 5351-5360. [CrossRef]

131. Ziebarth, A.J.; Nowsheen, S.; Steg, A.D.; Shah, M.M.; Katre, A.A.; Dobbin, Z.C.; Han, H.D.; Lopez-Berestein, G.; Sood, A.K.; Conner, M.; et al. Endoglin (CD105) contributes to platinum resistance and is a target for tumor-specific therapy in epithelial ovarian cancer. Clin. Cancer Res. 2013, 19, 170-182. [CrossRef]

132. Bai, S.; Zhu, W.; Coffman, L.; Vlad, A.; Schwartz, L.E.; Elishaev, E.; Drapkin, R.; Buckanovich, R.J. CD105 Is Expressed in Ovarian Cancer Precursor Lesions and Is Required for Metastasis to the Ovary. Cancers 2019, 11, 1710. [CrossRef]

133. Kauer, J.; Schwartz, K.; Tandler, C.; Hinterleitner, C.; Roerden, M.; Jung, G.; Salih, H.R.; Heitmann, J.S.; Marklin, M. CD105 (Endoglin) as negative prognostic factor in AML. Sci. Rep. 2019, 9, 18337. [CrossRef] [PubMed]

134. Madhav, A.; Andres, A.; Duong, F.; Mishra, R.; Haldar, S.; Liu, Z.; Angara, B.; Gottlieb, R.; Zumsteg, Z.S.; Bhowmick, N.A. Antagonizing CD105 enhances radiation sensitivity in prostate cancer. Oncogene 2018, 37, 4385-4397. [CrossRef] [PubMed]

135. Breen, M.J.; Moran, D.M.; Liu, W.; Huang, X.; Vary, C.P.; Bergan, R.C. Endoglin-mediated suppression of prostate cancer invasion is regulated by activin and bone morphogenetic protein type II receptors. PLoS ONE 2013, 8, e72407. [CrossRef]

136. Lakshman, M.; Huang, X.; Ananthanarayanan, V.; Jovanovic, B.; Liu, Y.; Craft, C.S.; Romero, D.; Vary, C.P.; Bergan, R.C. Endoglin suppresses human prostate cancer metastasis. Clin. Exp. Metastasis 2011, 28, 39-53. [CrossRef]

137. Liu, Y.; Jovanovic, B.; Pins, M.; Lee, C.; Bergan, R.C. Over expression of endoglin in human prostate cancer suppresses cell detachment, migration and invasion. Oncogene 2002, 21, 8272-8281. [CrossRef]

138. Romero, D.; Terzic, A.; Conley, B.A.; Craft, C.S.; Jovanovic, B.; Bergan, R.C.; Vary, C.P. Endoglin phosphorylation by ALK2 contributes to the regulation of prostate cancer cell migration. Carcinogenesis 2010, 31, 359-366. [CrossRef] [PubMed]

139. Craft, C.S.; Romero, D.; Vary, C.P.; Bergan, R.C. Endoglin inhibits prostate cancer motility via activation of the ALK2-Smad1 pathway. Oncogene 2007, 26, 7240-7250. [CrossRef] [PubMed]

140. Henry, L.A.; Johnson, D.A.; Sarrio, D.; Lee, S.; Quinlan, P.R.; Crook, T.; Thompson, A.M.; Reis-Filho, J.S.; Isacke, C.M. Endoglin expression in breast tumor cells suppresses invasion and metastasis and correlates with improved clinical outcome. Oncogene 2011, 30, 1046-1058. [CrossRef] [PubMed]

141. Wong, V.C.; Chan, P.L.; Bernabeu, C.; Law, S.; Wang, L.D.; Li, J.L.; Tsao, S.W.; Srivastava, G.; Lung, M.L. Identification of an invasion and tumor-suppressing gene, Endoglin (ENG), silenced by both epigenetic inactivation and allelic loss in esophageal squamous cell carcinoma. Int. J. Cancer 2008, 123, 2816-2823. [CrossRef]

142. Quail, D.F.; Joyce, J.A. Microenvironmental regulation of tumor progression and metastasis. Nat. Med. 2013, $19,1423-1437$. [CrossRef]

143. Casey, S.C.; Amedei, A.; Aquilano, K.; Azmi, A.S.; Benencia, F.; Bhakta, D.; Bilsland, A.E.; Boosani, C.S.; Chen, S.; Ciriolo, M.R.; et al. Cancer prevention and therapy through the modulation of the tumor microenvironment. Semin Cancer Biol. 2015, 35, S199-S223. [CrossRef]

144. Zhang, S.; Yang, X.; Wang, L.; Zhang, C. Interplay between inflammatory tumor microenvironment and cancer stem cells. Oncol. Lett. 2018, 16, 679-686. [CrossRef] [PubMed]

145. Nassiri, F.; Cusimano, M.D.; Scheithauer, B.W.; Rotondo, F.; Fazio, A.; Yousef, G.M.; Syro, L.V.; Kovacs, K.; Lloyd, R.V. Endoglin (CD105): A review of its role in angiogenesis and tumor diagnosis, progression and therapy. Anticancer Res. 2011, 31, $2283-2290$.

146. Dias, A.I.; Fachin, C.G.; Avo, L.R.; Frazao, C.V.; Caran, E.M.; Schettini, S.T.; Alves, M.T.; Ribeiro, R.C.; Abib Sde, C. Correlation between selected angiogenic markers and prognosis in pediatric adrenocortical tumors: Angiogenic markers and prognosis in pediatric ACTs. J. Pediatr. Surg. 2015, 50, 1323-1328. [CrossRef] [PubMed] 
147. Di Paolo, V.; Russo, I.; Boldrini, R.; Rava, L.; Pezzullo, M.; Benedetti, M.C.; Galardi, A.; Colletti, M.; Rota, R.; Orlando, D.; et al. Evaluation of Endoglin (CD105) expression in pediatric rhabdomyosarcoma. BMC Cancer 2018, 18, 31. [CrossRef] [PubMed]

148. Ollauri-Ibanez, C.; Nunez-Gomez, E.; Egido-Turrion, C.; Silva-Sousa, L.; Diaz-Rodriguez, E.; Rodriguez-Barbero, A.; LopezNovoa, J.M.; Pericacho, M. Continuous endoglin (CD105) overexpression disrupts angiogenesis and facilitates tumor cell metastasis. Angiogenesis 2020, 23, 231-247. [CrossRef]

149. Xu, Y.; Wang, D.; Zhao, L.M.; Zhao, X.L.; Shen, J.J.; Xie, Y.; Cao, L.L.; Chen, Z.B.; Luo, Y.M.; Bao, B.H.; et al. Endoglin is necessary for angiogenesis in human ovarian carcinoma-derived primary endothelial cells. Cancer Biol. Ther. 2013, 14, 937-948. [CrossRef] [PubMed]

150. Dolinsek, T.; Markelc, B.; Sersa, G.; Coer, A.; Stimac, M.; Lavrencak, J.; Brozic, A.; Kranjc, S.; Cemazar, M. Multiple delivery of siRNA against endoglin into murine mammary adenocarcinoma prevents angiogenesis and delays tumor growth. PLoS ONE 2013, 8, e58723. [CrossRef] [PubMed]

151. Duwel, A.; Eleno, N.; Jerkic, M.; Arevalo, M.; Bolanos, J.P.; Bernabeu, C.; Lopez-Novoa, J.M. Reduced tumor growth and angiogenesis in endoglin-haploinsufficient mice. Tumour Biol. 2007, 28, 1-8. [CrossRef] [PubMed]

152. Romero, D.; O’Neill, C.; Terzic, A.; Contois, L.; Young, K.; Conley, B.A.; Bergan, R.C.; Brooks, P.C.; Vary, C.P. Endoglin regulates cancer-stromal cell interactions in prostate tumors. Cancer Res. 2011, 71, 3482-3493. [CrossRef] [PubMed]

153. Anderberg, C.; Cunha, S.I.; Zhai, Z.; Cortez, E.; Pardali, E.; Johnson, J.R.; Franco, M.; Paez-Ribes, M.; Cordiner, R.; Fuxe, J.; et al. Deficiency for endoglin in tumor vasculature weakens the endothelial barrier to metastatic dissemination. J. Exp. Med. 2013, 210, 563-579. [CrossRef] [PubMed]

154. Ollauri-Ibanez, C.; Lopez-Novoa, J.M.; Pericacho, M. Endoglin-based biological therapy in the treatment of angiogenesisdependent pathologies. Expert Opin. Biol. Ther. 2017, 17, 1053-1063. [CrossRef] [PubMed]

155. Li, T.; Kang, G.; Wang, T.; Huang, H. Tumor angiogenesis and anti-angiogenic gene therapy for cancer. Oncol. Lett. 2018, 16, 687-702. [CrossRef]

156. Paauwe, M.; ten Dijke, P.; Hawinkels, L.J. Endoglin for tumor imaging and targeted cancer therapy. Expert Opin. Ther. Targets 2013, 17, 421-435. [CrossRef] [PubMed]

157. Maleki, M.; Ghanbarvand, F.; Reza Behvarz, M.; Ejtemaei, M.; Ghadirkhomi, E. Comparison of mesenchymal stem cell markers in multiple human adult stem cells. Int. J. Stem Cells 2014, 7, 118-126. [CrossRef] [PubMed]

158. Chiba, H.; Ishii, G.; Ito, T.K.; Aoyagi, K.; Sasaki, H.; Nagai, K.; Ochiai, A. CD105-positive cells in pulmonary arterial blood of adult human lung cancer patients include mesenchymal progenitors. Stem Cells 2008, 26, 2523-2530. [CrossRef] [PubMed]

159. Khan, M.I.; Czarnecka, A.M.; Lewicki, S.; Helbrecht, I.; Brodaczewska, K.; Koch, I.; Zdanowski, R.; Krol, M.; Szczylik, C. Comparative Gene Expression Profiling of Primary and Metastatic Renal Cell Carcinoma Stem Cell-Like Cancer Cells. PLoS ONE 2016, 11, e0165718. [CrossRef]

160. Shinojima, N.; Hossain, A.; Takezaki, T.; Fueyo, J.; Gumin, J.; Gao, F.; Nwajei, F.; Marini, F.C.; Andreeff, M.; Kuratsu, J.; et al. TGF-beta mediates homing of bone marrow-derived human mesenchymal stem cells to glioma stem cells. Cancer Res. 2013, 73, 2333-2344. [CrossRef] [PubMed]

161. Mardomi, A.; Sabzichi, M.; Hussein Somi, M.; Shanehbandi, D.; Rahbarghazi, R.; Taj Sanjarani, O.; Samadi, N. Trafficking mechanism of bone marrow-derived mesenchymal stem cells toward hepatocellular carcinoma HepG2 cells by modulating Endoglin, CXCR4 and TGF-beta. Cell. Mol. Biol. 2016, 62, 81-86. [PubMed]

162. Goldstein, R.H.; Reagan, M.R.; Anderson, K.; Kaplan, D.L.; Rosenblatt, M. Human bone marrow-derived MSCs can home to orthotopic breast cancer tumors and promote bone metastasis. Cancer Res. 2010, 70, 10044-10050. [CrossRef] [PubMed]

163. Prantl, L.; Muehlberg, F.; Navone, N.M.; Song, Y.H.; Vykoukal, J.; Logothetis, C.J.; Alt, E.U. Adipose tissue-derived stem cells promote prostate tumor growth. Prostate 2010, 70, 1709-1715. [CrossRef] [PubMed]

164. Suzuki, K.; Sun, R.; Origuchi, M.; Kanehira, M.; Takahata, T.; Itoh, J.; Umezawa, A.; Kijima, H.; Fukuda, S.; Saijo, Y. Mesenchymal stromal cells promote tumor growth through the enhancement of neovascularization. Mol. Med. 2011, 17, 579-587. [CrossRef] [PubMed]

165. Kucerova, L.; Matuskova, M.; Hlubinova, K.; Altanerova, V.; Altaner, C. Tumor cell behaviour modulation by mesenchymal stromal cells. Mol. Cancer 2010, 9, 129. [CrossRef]

166. Numakura, S.; Uozaki, H.; Kikuchi, Y.; Watabe, S.; Togashi, A.; Watanabe, M. Mesenchymal Stem Cell Marker Expression in Gastric Cancer Stroma. Anticancer Res. 2019, 39, 387-393. [CrossRef] [PubMed]

167. Ramasamy, R.; Lam, E.W.; Soeiro, I.; Tisato, V.; Bonnet, D.; Dazzi, F. Mesenchymal stem cells inhibit proliferation and apoptosis of tumor cells: Impact on in vivo tumor growth. Leukemia 2007, 21, 304-310. [CrossRef]

168. Qiao, L.; Xu, Z.; Zhao, T.; Zhao, Z.; Shi, M.; Zhao, R.C.; Ye, L.; Zhang, X. Suppression of tumorigenesis by human mesenchymal stem cells in a hepatoma model. Cell Res. 2008, 18, 500-507. [CrossRef]

169. Paauwe, M.; Schoonderwoerd, M.J.A.; Helderman, R.; Harryvan, T.J.; Groenewoud, A.; van Pelt, G.W.; Bor, R.; Hemmer, D.M.; Versteeg, H.H.; Snaar-Jagalska, B.E.; et al. Endoglin Expression on Cancer-Associated Fibroblasts Regulates Invasion and Stimulates Colorectal Cancer Metastasis. Clin. Cancer Res. 2018, 24, 6331-6344. [CrossRef]

170. Kato, M.; Placencio-Hickok, V.R.; Madhav, A.; Haldar, S.; Tripathi, M.; Billet, S.; Mishra, R.; Smith, B.; Rohena-Rivera, K.; Agarwal, P.; et al. Heterogeneous cancer-associated fibroblast population potentiates neuroendocrine differentiation and castrate resistance in a CD105-dependent manner. Oncogene 2019, 38, 716-730. [CrossRef] 
171. Paauwe, M.; Heijkants, R.C.; Oudt, C.H.; van Pelt, G.W.; Cui, C.; Theuer, C.P.; Hardwick, J.C.; Sier, C.F.; Hawinkels, L.J. Endoglin targeting inhibits tumor angiogenesis and metastatic spread in breast cancer. Oncogene 2016, 35, 4069-4079. [CrossRef] [PubMed]

172. Schmidt-Weber, C.B.; Letarte, M.; Kunzmann, S.; Ruckert, B.; Bernabeu, C.; Blaser, K. TGF-\{beta\} signaling of human T cells is modulated by the ancillary TGF-\{beta\} receptor endoglin. Int. Immunol. 2005, 17, 921-930. [CrossRef]

173. Schoonderwoerd, M.J.A.; Koops, M.F.M.; Angela, R.A.; Koolmoes, B.; Toitou, M.; Paauwe, M.; Barnhoorn, M.C.; Liu, Y.; Sier, C.F.M.; Hardwick, J.C.H.; et al. Targeting Endoglin-Expressing Regulatory T Cells in the Tumor Microenvironment Enhances the Effect of PD1 Checkpoint Inhibitor Immunotherapy. Clin. Cancer Res. 2020, 26, 3831-3842. [CrossRef] [PubMed]

174. Apolo, A.B.; Karzai, F.H.; Trepel, J.B.; Alarcon, S.; Lee, S.; Lee, M.J.; Tomita, Y.; Cao, L.; Yu, Y.; Merino, M.J.; et al. A Phase II Clinical Trial of TRC105 (Anti-Endoglin Antibody) in Adults With Advanced/Metastatic Urothelial Carcinoma. Clin. Genitourin. Cancer 2017, 15, 77-85. [CrossRef]

175. Karzai, F.H.; Apolo, A.B.; Cao, L.; Madan, R.A.; Adelberg, D.E.; Parnes, H.; McLeod, D.G.; Harold, N.; Peer, C.; Yu, Y.; et al. A phase I study of TRC105 anti-endoglin (CD105) antibody in metastatic castration-resistant prostate cancer. BJU Int. 2015, 116, 546-555. [CrossRef] [PubMed]

176. Ojeda-Fernandez, L.; Recio-Poveda, L.; Aristorena, M.; Lastres, P.; Blanco, F.J.; Sanz-Rodriguez, F.; Gallardo-Vara, E.; de las Casas-Engel, M.; Corbi, A.; Arthur, H.M.; et al. Mice Lacking Endoglin in Macrophages Show an Impaired Immune Response. PLoS Genet. 2016, 12, e1005935. [CrossRef]

177. O'Connell, P.J.; McKenzie, A.; Fisicaro, N.; Rockman, S.P.; Pearse, M.J.; d'Apice, A.J. Endoglin: A 180-kD endothelial cell and macrophage restricted differentiation molecule. Clin. Exp. Immunol. 1992, 90, 154-159. [CrossRef]

178. Jarosz-Biej, M.; Kaminska, N.; Matuszczak, S.; Cichon, T.; Pamula-Pilat, J.; Czapla, J.; Smolarczyk, R.; Skwarzynska, D.; Kulik, K.; Szala, S. M1-like macrophages change tumor blood vessels and microenvironment in murine melanoma. PLoS ONE 2018, 13, e0191012. [CrossRef]

179. Maciel, T.T.; Moura, I.C.; Hermine, O. The role of mast cells in cancers. F1000Prime Rep. 2015, 7, 9. [CrossRef] [PubMed]

180. Wu, H.W.; Sheard, M.A.; Malvar, J.; Fernandez, G.E.; DeClerck, Y.A.; Blavier, L.; Shimada, H.; Theuer, C.P.; Sposto, R.; Seeger, R.C. Anti-CD105 Antibody Eliminates Tumor Microenvironment Cells and Enhances Anti-GD2 Antibody Immunotherapy of Neuroblastoma with Activated Natural Killer Cells. Clin. Cancer Res. 2019, 25, 4761-4774. [CrossRef]

181. Peinado, H.; Lavotshkin, S.; Lyden, D. The secreted factors responsible for pre-metastatic niche formation: Old sayings and new thoughts. Semin. Cancer Biol. 2011, 21, 139-146. [CrossRef] [PubMed]

182. Peinado, H.; Zhang, H.; Matei, I.R.; Costa-Silva, B.; Hoshino, A.; Rodrigues, G.; Psaila, B.; Kaplan, R.N.; Bromberg, J.F.; Kang, Y.; et al. Pre-metastatic niches: Organ-specific homes for metastases. Nat. Rev. Cancer 2017, 17, 302-317. [CrossRef]

183. Hawinkels, L.J.; Kuiper, P.; Wiercinska, E.; Verspaget, H.W.; Liu, Z.; Pardali, E.; Sier, C.F.; ten Dijke, P. Matrix metalloproteinase-14 (MT1-MMP)-mediated endoglin shedding inhibits tumor angiogenesis. Cancer Res. 2010, 70, 4141-4150. [CrossRef]

184. Kumar, S.; Pan, C.C.; Bloodworth, J.C.; Nixon, A.B.; Theuer, C.; Hoyt, D.G.; Lee, N.Y. Antibody-directed coupling of endoglin and MMP-14 is a key mechanism for endoglin shedding and deregulation of TGF-beta signaling. Oncogene 2014, 33, 3970-3979. [CrossRef]

185. Tobar, N.; Avalos, M.C.; Mendez, N.; Smith, P.C.; Bernabeu, C.; Quintanilla, M.; Martinez, J. Soluble MMP-14 produced by bone marrow-derived stromal cells sheds epithelial endoglin modulating the migratory properties of human breast cancer cells. Carcinogenesis 2014, 35, 1770-1779. [CrossRef]

186. Olsen, O.E.; Wader, K.F.; Misund, K.; Vatsveen, T.K.; Ro, T.B.; Mylin, A.K.; Turesson, I.; Stordal, B.F.; Moen, S.H.; Standal, T.; et al. Bone morphogenetic protein-9 suppresses growth of myeloma cells by signaling through ALK2 but is inhibited by endoglin. Blood Cancer J. 2014, 4, e196. [CrossRef]

187. Takahashi, N.; Kawanishi-Tabata, R.; Haba, A.; Tabata, M.; Haruta, Y.; Tsai, H.; Seon, B.K. Association of serum endoglin with metastasis in patients with colorectal, breast, and other solid tumors, and suppressive effect of chemotherapy on the serum endoglin. Clin. Cancer Res. 2001, 7, 524-532.

188. Li, C.; Guo, B.; Wilson, P.B.; Stewart, A.; Byrne, G.; Bundred, N.; Kumar, S. Plasma levels of soluble CD105 correlate with metastasis in patients with breast cancer. Int. J. Cancer 2000, 89, 122-126. [CrossRef]

189. Webber, J.; Yeung, V.; Clayton, A. Extracellular vesicles as modulators of the cancer microenvironment. Semin. Cell Dev. Biol. 2015, 40, 27-34. [CrossRef] [PubMed]

190. Becker, A.; Thakur, B.K.; Weiss, J.M.; Kim, H.S.; Peinado, H.; Lyden, D. Extracellular Vesicles in Cancer: Cell-to-Cell Mediators of Metastasis. Cancer Cell 2016, 30, 836-848. [CrossRef] [PubMed]

191. Grange, C.; Tapparo, M.; Collino, F.; Vitillo, L.; Damasco, C.; Deregibus, M.C.; Tetta, C.; Bussolati, B.; Camussi, G. Microvesicles released from human renal cancer stem cells stimulate angiogenesis and formation of lung premetastatic niche. Cancer Res. 2011, 71, 5346-5356. [CrossRef]

192. Yang, Y.; Otte, A.; Hass, R. Human mesenchymal stroma/stem cells exchange membrane proteins and alter functionality during interaction with different tumor cell lines. Stem Cells Dev. 2015, 24, 1205-1222. [CrossRef] [PubMed]

193. Van Laake, L.W.; van den Driesche, S.; Post, S.; Feijen, A.; Jansen, M.A.; Driessens, M.H.; Mager, J.J.; Snijder, R.J.; Westermann, C.J.; Doevendans, P.A.; et al. Endoglin has a crucial role in blood cell-mediated vascular repair. Circulation 2006, 114, $2288-2297$. [CrossRef] [PubMed]

194. Kapur, N.K.; Morine, K.J.; Letarte, M. Endoglin: A critical mediator of cardiovascular health. Vasc. Health Risk Manag. 2013, 9 , 195-206. [CrossRef] [PubMed] 
195. Valluru, M.; Staton, C.A.; Reed, M.W.; Brown, N.J. Transforming Growth Factor-beta and Endoglin Signaling Orchestrate Wound Healing. Front. Physiol. 2011, 2, 89. [CrossRef] [PubMed]

196. Duffy, A.G.; Ulahannan, S.V.; Cao, L.; Rahma, O.E.; Makarova-Rusher, O.V.; Kleiner, D.E.; Fioravanti, S.; Walker, M.; Carey, S.; Yu, Y.; et al. A phase II study of TRC105 in patients with hepatocellular carcinoma who have progressed on sorafenib. United Eur. Gastroenterol. J. 2015, 3, 453-461. [CrossRef] [PubMed]

197. Kelsey, R. Prostate cancer: Phase I study shows potential of TRC105 in mCRPC. Nat. Rev. Urol. 2015, 12, 6. [CrossRef] [PubMed]

198. Gordon, M.S.; Robert, F.; Matei, D.; Mendelson, D.S.; Goldman, J.W.; Chiorean, E.G.; Strother, R.M.; Seon, B.K.; Figg, W.D.; Peer, C.J.; et al. An open-label phase Ib dose-escalation study of TRC105 (anti-endoglin antibody) with bevacizumab in patients with advanced cancer. Clin. Cancer Res. 2014, 20, 5918-5926. [CrossRef] [PubMed]

199. Liu, Y.; Tian, H.; Blobe, G.C.; Theuer, C.P.; Hurwitz, H.I.; Nixon, A.B. Effects of the combination of TRC105 and bevacizumab on endothelial cell biology. Investig. New Drugs 2014, 32, 851-859. [CrossRef] [PubMed]

200. Liu, Y.; Starr, M.D.; Brady, J.C.; Dellinger, A.; Pang, H.; Adams, B.; Theuer, C.P.; Lee, N.Y.; Hurwitz, H.I.; Nixon, A.B. Modulation of circulating protein biomarkers following TRC105 (anti-endoglin antibody) treatment in patients with advanced cancer. Cancer Med. 2014, 3, 580-591. [CrossRef] [PubMed]

201. Karmani, L.; Bouchat, V.; Bouzin, C.; Leveque, P.; Labar, D.; Bol, A.; Deumer, G.; Marega, R.; Bonifazi, D.; Haufroid, V.; et al. (89)Zr-labeled anti-endoglin antibody-targeted gold nanoparticles for imaging cancer: Implications for future cancer therapy. Nanomedicine 2014, 9, 1923-1937. [CrossRef]

202. Chopra, A. (89)Zr-Labeled anti-CD105 (endoglin) chimeric monoclonal antibody TRC105 linked to IRDye 800CW. In Molecular Imaging and Contrast Agent Database (MICAD); National Center for Biotechnology Information (US): Bethesda, MD, USA, 2004.

203. Rosen, L.S.; Hurwitz, H.I.; Wong, M.K.; Goldman, J.; Mendelson, D.S.; Figg, W.D.; Spencer, S.; Adams, B.J.; Alvarez, D.; Seon, B.K.; et al. A phase I first-in-human study of TRC105 (Anti-Endoglin Antibody) in patients with advanced cancer. Clin. Cancer Res. 2012, 18, 4820-4829. [CrossRef] [PubMed]

204. Jarosz, M.; Jazowiecka-Rakus, J.; Cichon, T.; Glowala-Kosinska, M.; Smolarczyk, R.; Smagur, A.; Malina, S.; Sochanik, A.; Szala, S. Therapeutic antitumor potential of endoglin-based DNA vaccine combined with immunomodulatory agents. Gene Ther. 2013, 20, 262-273. [CrossRef]

205. Uneda, S.; Toi, H.; Tsujie, T.; Tsujie, M.; Harada, N.; Tsai, H.; Seon, B.K. Anti-endoglin monoclonal antibodies are effective for suppressing metastasis and the primary tumors by targeting tumor vasculature. Int. J. Cancer 2009, 125, 1446-1453. [CrossRef] [PubMed]

206. Gan, H.K.; van den Bent, M.; Lassman, A.B.; Reardon, D.A.; Scott, A.M. Antibody-drug conjugates in glioblastoma therapy: The right drugs to the right cells. Nat. Rev. Clin. Oncol. 2017, 14, 695-707. [CrossRef]

207. Duffy, A.G.; Ma, C.; Ulahannan, S.V.; Rahma, O.E.; Makarova-Rusher, O.; Cao, L.; Yu, Y.; Kleiner, D.E.; Trepel, J.; Lee, M.J.; et al. Phase I and Preliminary Phase II Study of TRC105 in Combination with Sorafenib in Hepatocellular Carcinoma. Clin. Cancer Res. 2017, 23, 4633-4641. [CrossRef]

208. Shih, T.; Lindley, C. Bevacizumab: An angiogenesis inhibitor for the treatment of solid malignancies. Clin. Ther. 2006, 28, 1779-1802. [CrossRef] [PubMed]

209. Khan, K.A.; Bicknell, R. Anti-angiogenic alternatives to VEGF blockade. Clin. Exp. Metastasis 2016, 33, 197-210. [CrossRef] [PubMed]

210. Attia, S.; Sankhala, K.K.; Riedel, R.F.; Robinson, S.I.; Conry, R.M.; Boland, P.M.; Barve, M.A.; Fritchie, K.; Seon, B.K.; Alvarez, D.; et al. A phase 1B/ phase 2A study of TRC105 (Endoglin Antibody) in combination with pazopanib (P) in patients (pts) with advanced soft tissue sarcoma (STS). J. Clin. Oncol. 2016, 34, 11016. [CrossRef]

211. Young, R.J.; Woll, P.J. Anti-angiogenic therapies for the treatment of angiosarcoma: A clinical update. Memo 2017, 10, 190-193. [CrossRef]

212. Choueiri, T.K.; Michaelson, M.D.; Posadas, E.M.; Sonpavde, G.P.; McDermott, D.F.; Nixon, A.B.; Liu, Y.; Yuan, Z.; Seon, B.K.; Walsh, M.; et al. An Open Label Phase Ib Dose Escalation Study of TRC105 (Anti-Endoglin Antibody) with Axitinib in Patients with Metastatic Renal Cell Carcinoma. Oncologist 2019, 24, 202-210. [CrossRef]

213. Beck, A.; Goetsch, L.; Dumontet, C.; Corvaia, N. Strategies and challenges for the next generation of antibody-drug conjugates. Nat. Rev. Drug Discov. 2017, 16, 315-337. [CrossRef] [PubMed]

214. Zolot, R.S.; Basu, S.; Million, R.P. Antibody-drug conjugates. Nat. Rev. Drug Discov. 2013, 12, 259-260. [CrossRef] [PubMed]

215. Puerto-Camacho, P.; Amaral, A.T.; Lamhamedi-Cherradi, S.E.; Menegaz, B.A.; Castillo-Ecija, H.; Ordonez, J.L.; Dominguez, S.; Jordan-Perez, C.; Diaz-Martin, J.; Romero-Perez, L.; et al. Preclinical Efficacy of Endoglin-Targeting Antibody-Drug Conjugates for the Treatment of Ewing Sarcoma. Clin. Cancer Res. 2019, 25, 2228-2240. [CrossRef]

216. Chen, F.; Nayak, T.R.; Goel, S.; Valdovinos, H.F.; Hong, H.; Theuer, C.P.; Barnhart, T.E.; Cai, W. In vivo tumor vasculature targeted PET/NIRF imaging with TRC105(Fab)-conjugated, dual-labeled mesoporous silica nanoparticles. Mol. Pharm. 2014, 11, 4007-4014. [CrossRef] [PubMed]

217. Lee, S.H.; Mizutani, N.; Mizutani, M.; Luo, Y.; Zhou, H.; Kaplan, C.; Kim, S.W.; Xiang, R.; Reisfeld, R.A. Endoglin (CD105) is a target for an oral DNA vaccine against breast cancer. Cancer Immunol. Immunother. 2006, 55, 1565-1574. [CrossRef]

218. Fujita, K.; Ewing, C.M.; Chan, D.Y.; Mangold, L.A.; Partin, A.W.; Isaacs, W.B.; Pavlovich, C.P. Endoglin (CD105) as a urinary and serum marker of prostate cancer. Int. J. Cancer 2009, 124, 664-669. [CrossRef] 
219. Svatek, R.S.; Karam, J.A.; Roehrborn, C.G.; Karakiewicz, P.I.; Slawin, K.M.; Shariat, S.F. Preoperative plasma endoglin levels predict biochemical progression after radical prostatectomy. Clin. Cancer Res. 2008, 14, 3362-3366. [CrossRef]

220. Karam, J.A.; Svatek, R.S.; Karakiewicz, P.I.; Gallina, A.; Roehrborn, C.G.; Slawin, K.M.; Shariat, S.F. Use of preoperative plasma endoglin for prediction of lymph node metastasis in patients with clinically localized prostate cancer. Clin. Cancer Res. 2008, 14, 1418-1422. [CrossRef] [PubMed]

221. Calabro, L.; Fonsatti, E.; Bellomo, G.; Alonci, A.; Colizzi, F.; Sigalotti, L.; Altomonte, M.; Musolino, C.; Maio, M. Differential levels of soluble endoglin (CD105) in myeloid malignancies. J. Cell Physiol. 2003, 194, 171-175. [CrossRef]

222. Liu, Z.; Afink, G.B.; Dijke, P.T. Soluble fms-like tyrosine kinase 1 and soluble endoglin are elevated circulating anti-angiogenic factors in pre-eclampsia. Pregnancy Hypertens. 2012, 2, 358-367. [CrossRef] [PubMed]

223. Lopez-Novoa, J.M. Soluble endoglin is an accurate predictor and a pathogenic molecule in pre-eclampsia. Nephrol. Dial. Transplant. 2007, 22, 712-714. [CrossRef]

224. Luft, F.C. Soluble endoglin (sEng) joins the soluble fms-like tyrosine kinase (sFlt) receptor as a pre-eclampsia molecule. Nephrol. Dial. Transplant. 2006, 21, 3052-3054. [CrossRef]

225. Venkatesha, S.; Toporsian, M.; Lam, C.; Hanai, J.; Mammoto, T.; Kim, Y.M.; Bdolah, Y.; Lim, K.H.; Yuan, H.T.; Libermann, T.A.; et al. Soluble endoglin contributes to the pathogenesis of preeclampsia. Nat. Med. 2006, 12, 642-649. [CrossRef] [PubMed]

226. Phipps, E.A.; Thadhani, R.; Benzing, T.; Karumanchi, S.A. Pre-eclampsia: Pathogenesis, novel diagnostics and therapies. Nat. Rev. Nephrol. 2019, 15, 275-289. [CrossRef] [PubMed]

227. Levine, R.J.; Lam, C.; Qian, C.; Yu, K.F.; Maynard, S.E.; Sachs, B.P.; Sibai, B.M.; Epstein, F.H.; Romero, R.; Thadhani, R.; et al. Soluble endoglin and other circulating antiangiogenic factors in preeclampsia. N. Engl. J. Med. 2006, 355, 992-1005. [CrossRef]

228. Vitkova, V.; Panek, M.; Janec, P.; Sibikova, M.; Vobruba, V.; Haluzik, M.; Zivny, J.; Janota, J. Endothelial Microvesicles and Soluble Markers of Endothelial Injury in Critically Ill Newborns. Mediat. Inflamm. 2018, 2018, 1975056. [CrossRef]

229. Tannetta, D.S.; Dragovic, R.A.; Gardiner, C.; Redman, C.W.; Sargent, I.L. Characterisation of syncytiotrophoblast vesicles in normal pregnancy and pre-eclampsia: Expression of Flt-1 and endoglin. PLoS ONE 2013, 8, e56754. [CrossRef] [PubMed] 